Int. J. Dev. Biol. 57: 595-610 (2013)

doi: $10.1387 / \mathrm{ijdb} .130268 \mathrm{lh}$

\title{
Biotechnology of nutrient uptake and assimilation in plants
}

\author{
DAMAR L. LÓPEZ-ARREDONDO' ${ }^{1}$ MARCO A. LEYVA-GONZÁLEZ1, \\ FULGENCIO ALATORRE-COBOS ${ }^{2}$ and LUIS HERRERA-ESTRELLA*,2 \\ 'StelaGenomics México and ${ }^{2}$ Laboratorio Nacional de Genómica para la Biodiversidad, Centro de Investigación y de \\ Estudios Avanzados del Instituto Politécnico Nacional, Irapuato, Guanajuato, México
}

\begin{abstract}
Plants require a complex balance of mineral nutrients to reproduce successfully. Because the availability of many of these nutrients in the soil is compromised by several factors, such as soil pH, cation presence, and microbial activity, crop plants depend directly on nutrients applied as fertilizers to achieve high yields. However, the excessive use of fertilizers is a major environmental concern due to nutrient leaching that causes water eutrophication and promotes toxic algae blooms. This situation generates the urgent need for crop plants with increased nutrient use efficiency and better-designed fertilization schemes. The plant biology revolution triggered by the development of efficient gene transfer systems for plant cells together with the more recent development of next-generation DNA and RNA sequencing and other omics platforms have advanced considerably our understanding on the molecular basis of plant nutrition and how plants respond to nutritional stress. To date, genes encoding sensors, transcription factors, transporters, and metabolic enzymes have been identified as potential candidates to improve nutrient use efficiency. In addition, the study of other genetic resources, such as bacteria and fungi, allows the identification of alternative mechanisms of nutrient assimilation, which are potentially applicable in plants. Although significant progress in this respect has been achieved by conventional breeding, in this review we focus on the biotechnological approaches reported to date aimed at boosting the use of the three most limiting nutrients in the majority of arable lands: nitrogen, phosphorus, and iron.
\end{abstract}

KEY WORDS: plant nutrition, macronutrients, grain yield, gene overexpression, bacterial gene, biotechnology

\section{Introduction}

Mineral elements, such as phosphorus $(\mathrm{P})$, nitrogen $(\mathrm{N})$, calcium $(\mathrm{Ca})$, iron (Fe), zinc $(\mathrm{Zn})$, magnesium $(\mathrm{Mg})$, and manganese $(\mathrm{Mn})$, among others, play essential roles in all living organisms. An appropriate balance of all these nutrients is necessary at each stage of plant development to achieve maximum yield. Plants require large amounts of $\mathrm{P}$ and $\mathrm{N}$ that are key nutrients because they are building blocks for fundamental biological molecules, such as nucleotides, amino acids, and proteins, whereas they need only small amounts of micronutrients, such as Fe, Zn, and boron, which generally act as cofactors in enzymatic reactions. However, in most soils, one or more of these nutrients is in short supply or unavailable for plant uptake as a consequence of different factors, such as low diffusion rates, rhizosphere microbial activity, and soil physicochemical properties. Among all the vital nutrients for plants, $\mathrm{P}$ and $\mathrm{N}$ are the most limiting factors for agricultural production, making necessary the application of high amounts of fertilizers each year to increase crop yield.
Since the Green Revolution, in the past 60 years, worldwide food production has increased dramatically thanks to the introduction of improved crop varieties, but also to an enhanced use of fertilizers and other agrochemicals. Currently, nearly 50 million

Abbreviations used in this paper: BBP, $\beta$-propeller phytase; CIPK, CALCINEURIN B-LIKE-INTERACTING PROTEIN KINASE; CK, cytokinin; DMA, deoxymugineic acid; fdr, ferric-chelate reductase defective mutant; FER, Fe-uptake response; FIT, FER-LIKE IRON DEFICIENCY INDUCED; FRO, FERRIC CHELATE REDUCTASE OXIDASE; Gln, glutamine; Glu, glutamate; GOGAT, glutamine2-oxoglutarate aminotransferase; GS, glutamine synthetase; HAP, histidine acid phosphatase; HATS, high-affinity transport systems; IDEF, IRON DEFICIENCYRESPONSIVE ELEMENT-BINDING FACTORS; IDS, IRON-DEFICIENCY SPECIFIC CLONE; IRO, IRON-RELATEDTRANSCRIPTIONFACTOR;IRT, IRON-REGULATED TRANSPORTER; LATS, low-affinity transport systems; LR, lateral root; MA, mugineic acid; NAS, nicotianamine synthase; NiR, nitrite reductase; NR, nitrate reductase; NUE, nutrient use efficiency; OA, organic acid; PAP, purple acid phosphatases; PEPc, phosphoenolpyruvate carboxylase (PEPc); Phi, phosphite; PHT, Pi transporter; $\mathrm{Pi}$, inorganic P; PR, primary root; PUE, Pi use efficiency; TF, transcription factor.

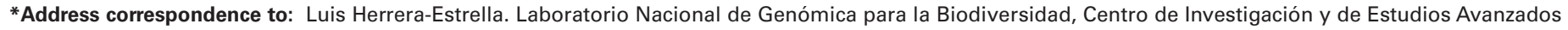
del Instituto Politécnico Nacional, Edificio Langebio A, Km 9.6 Libramiento Norte Carretera Irapuato-León, C.P. 36821, Irapuato, Guanajuato, Mexico. Tel.: +52 462 1663008. Fax: +52 +52 462 6245849. e-mail: Iherrera@ira.cinvestav.mx
} 
tons of $\mathrm{P}$ fertilizers, 110 million tons of $\mathrm{N}$ fertilizers, and 5 million tons of pesticides (of which $50 \%$ are herbicides) are applied worldwide (http://faostat.fao.org/site/339/default.aspx; http://www. fao.org/worldfoodsituation/wfs-home/csdb/en/; http://fertilizer.org/ ifa/Home-Page/STATISTICS; http://www.fertilizer.org/ifa/HomePage/SUSTAINABILITY/Fertilizer-Best-Management-Practices). Although the systematic introduction of improved crop varieties allowed an increase in cereal production from 824 million tons in 1960 to almost 2,400 million tons in 2011 (www.fas.usda.gov/ psdonline), traditional plant breeding programs appear insufficient to ensure future global food demands. Moreover, according to prognoses that take into account the current fertilizer consumption rate, 208 million tons of fertilizer will be needed to secure the global food demand in 2020 (Roy et al., 2006). Moreover, when soil nutrient depletion derived from intensive land use is taken into consideration, fertilizer consumption in 2020 could reach up to 300 million tons, unless new plant varieties or hybrids with enhanced nutrient use efficiency and/or improved fertilization schemes are developed and implemented (Cakmak, 2002). Therefore, modern breeding programs based on genomic information together with transgenic approaches are needed to increase food production while reducing the use of fertilizers and other agrochemicals.

Among the factors that contribute to excessive $\mathrm{N}$ and $\mathrm{P}$ fertilizer consumption, the most important are (i) fixation of a large percentage of the $\mathrm{P}$ fertilizers into the soil, by adsorption and reaction with cations; (ii) loss of highly soluble $\mathrm{N}$ compounds by run-off and volatilization; and (iii) strong competition from soil microorganisms and weeds for the available $\mathrm{N}$ and $\mathrm{P}$ fertilizers. Due to these factors, cultivated plants use effectively only $20 \%$ to $30 \%$ of the applied fertilizers. Excessive application of fertilizers not only increases food production costs but also seriously pollute the atmosphere and water bodies, such as rivers and oceans, leading to eutrophication and ocean-dead zones. Hence, the rational use of these resources is imperative to enhance crop yields through improvement of the $\mathrm{N}$ and $\mathrm{P}$ uptake and utilization efficiency. In other words, the challenge consists not only in the development of genotypes that use $\mathrm{N}$ and $\mathrm{P}$ more efficiently, but also in their implementation in better-designed agricultural schemes. Achieving these goals is particularly urgent in the case of $P$ because it is a nonrenewable resource, of which high-quality reserves have been predicted to last between 70 to 150 years if current use is maintained (Gilbert, 2009).

To produce improved plant varieties or hybrids, traditional breeding programs are based on trial-and-error strategies that are slow and require the analysis of thousands of cross-derived plants. Currently, knowledge-based breeding programs start to be designed thanks to the increasing information on plant biology that was initially triggered by the development of plant transgenesis and, more recently, by the implementation of next-generation DNA and RNA sequencing and other omics platforms. In particular, understanding the genetic basis of plant nutrition progresses rapidly and allows the identification and management of key regulatory elements involved in nutrient uptake, transport, and assimilation, as well as in root system morphology and physiology, such as ion transporters, transcription factors (TFs), and metabolic enzymes, of which overexpression or inactivation are becoming promising approaches to generate plants with improved nutrient use efficiency. In addition, because the human diet depend directly on the mineral composition of plants (such as cereal grains), increase in nutrient content and availability in agricultural products will have a positive impact. Here, we review the current knowledge on the key genes that regulate uptake and assimilation of $P, N$, and $\mathrm{Fe}$ in plants and on their application to improve nutrient use efficiency in several crops.

\section{Engineering plant nitrogen nutrition for a rational agriculture}

Not only is $\mathrm{N}$ an essential nutrient for plants, but also a signaling molecule that regulates important physiological and developmental processes, such as seed dormancy, flowering time, leaf expansion, root development and the expression of multiple $\mathrm{N}$-responsive genes (Bouguyon et al., 2012). Plants are able to use two types of $\mathrm{N}$-containing compounds as $\mathrm{N}$ sources: inorganic compounds, namely nitrate $\left(\mathrm{NO}_{3}{ }^{-}\right)$and ammonium $\left(\mathrm{NH}_{4}{ }^{+}\right)$and organic compounds, such as amino acids, peptides (di- and tri-peptides), and proteins (Miller et al., 2007). Under natural conditions, the content of organic and inorganic $\mathrm{N}$ sources in the soil is highly heterogeneous and dynamic, depending also on a variety of soil factors, such as temperature, $\mathrm{pH}$, chemical properties, and the presence of microorganisms. The availability of $\mathrm{NH}_{4}^{+}$, urea, amino acids, peptides, and proteins is limited in agricultural soils; therefore, $\mathrm{NO}_{3}^{-}$, supplied as fertilizer, is the major $\mathrm{N}$ source for most plants under aerobic soil conditions (Krouk et al., 2010). Hence, we will mainly discuss data regarding mechanisms for $\mathrm{NO}_{3}$ - uptake, transport, and assimilation as well as the more recent progress on the regulatory elements that control responses to low $\mathrm{NO}_{3}{ }^{-}$availability and their potential use to improve $\mathrm{N}$ metabolism in plants.

\section{Nitrogen uptake, transport, and assimilation in plants: a com- plex network of proteins}

Regulation of plant $\mathrm{N}$-metabolism in higher plants is highly complex and influenced by several physiological and metabolic processes such as sucrose synthesis and transport, circadian rhythms, key $\mathrm{N}$ metabolite levels (for instance, glutamine [GIn]), and $\mathrm{NO}_{3}^{-}$itself. Physiological studies revealed that different plant species are capable of responding to $\mathrm{N}$ availability by reprogramming their growth through modification of root system architecture, modulation of vacuolar $\mathrm{N}$ storage and remobilization, and activity of $\mathrm{NO}_{3}{ }^{-}$and $\mathrm{NH}_{4}{ }^{+}$transportsystems. Extensive transcriptome analyses revealed that the expression of numerous genes (up to $10 \%$ of the Arabidopsis thaliana genome) is modulated by $\mathrm{NO}_{3}^{-}$availability. The study of plant mutants together with genomic approaches has allowed the identification and functional characterization of several components of plant $\mathrm{N}$ responses, including specific $\mathrm{NO}_{3}{ }^{-}$and $\mathrm{NH}_{4}{ }^{+}$ transporters and transceptors (transporter/receptor) (Fig. 1A) as well as signaling components, including calcium-related protein kinases, TFs (Fig.1B), and some regulatory elements involved in responses to low $\mathrm{NO}_{3}^{-}$, particularly modulating root development (Fig. 1C).

\section{Nitrogen transport}

Plants have evolved sophisticated mechanisms to optimize and regulate the acquisition and assimilation of different $\mathrm{N}$ sources. $\mathrm{NO}_{3}$ uptake from the soil relies on the concerted action of low-affinity and high-affinity transport systems (LATS and HATS, respectively) that ensure the intake of adequate levels of $\mathrm{NO}_{3}^{-}$over a wide range of concentrations (Fig. 1A). Both LATS and $\mathrm{HATS} \mathrm{NO}_{3}^{-}$gene 
families include constitutive and $\mathrm{NO}_{3}$-inducible members (Miller et al., 2007). Until now, four $\mathrm{NO}_{3}^{-}$-transporter gene families are known, of which NITRATE TRANSPORTER1/PEPTIDE TRANSPORTER (NRT1/PTR) and NITRATE TRANSPORTER2 (NRT2) gene families are responsible for $\mathrm{NO}_{3}$ - uptake from the environment, the first also comprising transporters involved in $\mathrm{NO}_{3}^{-}$efflux, such as the NITRATE EXCRETION TRANSPORTER and NRT1.5 (for a detailed review see Wang et al., 2012).

The dual-affinity member of the NRT1/PTRgene family, NRT1.1 (also called CHLORATE RESISTANT1 [CHL 1]), and the NRT2.1, NRT2.2, and NRT2.4 members of the NRT2 gene family are HATS particularly important under low $\mathrm{NO}_{3}{ }^{-}$availability. In addition to their transport function, NRT1.1 and NRT2.1 are also involved in $\mathrm{NO}_{3}$ sensing (Fig. 1A). NRT1.1/CHL1 is an interesting case of a finely regulated gene: its expression is transcriptionally regulated by $\mathrm{NO}_{3}^{-}$, nitrite $\left(\mathrm{NO}_{2}{ }^{-}\right), \mathrm{NH}_{4}{ }^{+}$, Gln, $\mathrm{N}$ starvation, light, sucrose, diurnal rhythm and its transceptor activity depends on the phosphorylation of threonine 101 by CALCINEURIN B-LIKE-INTERACTING

A

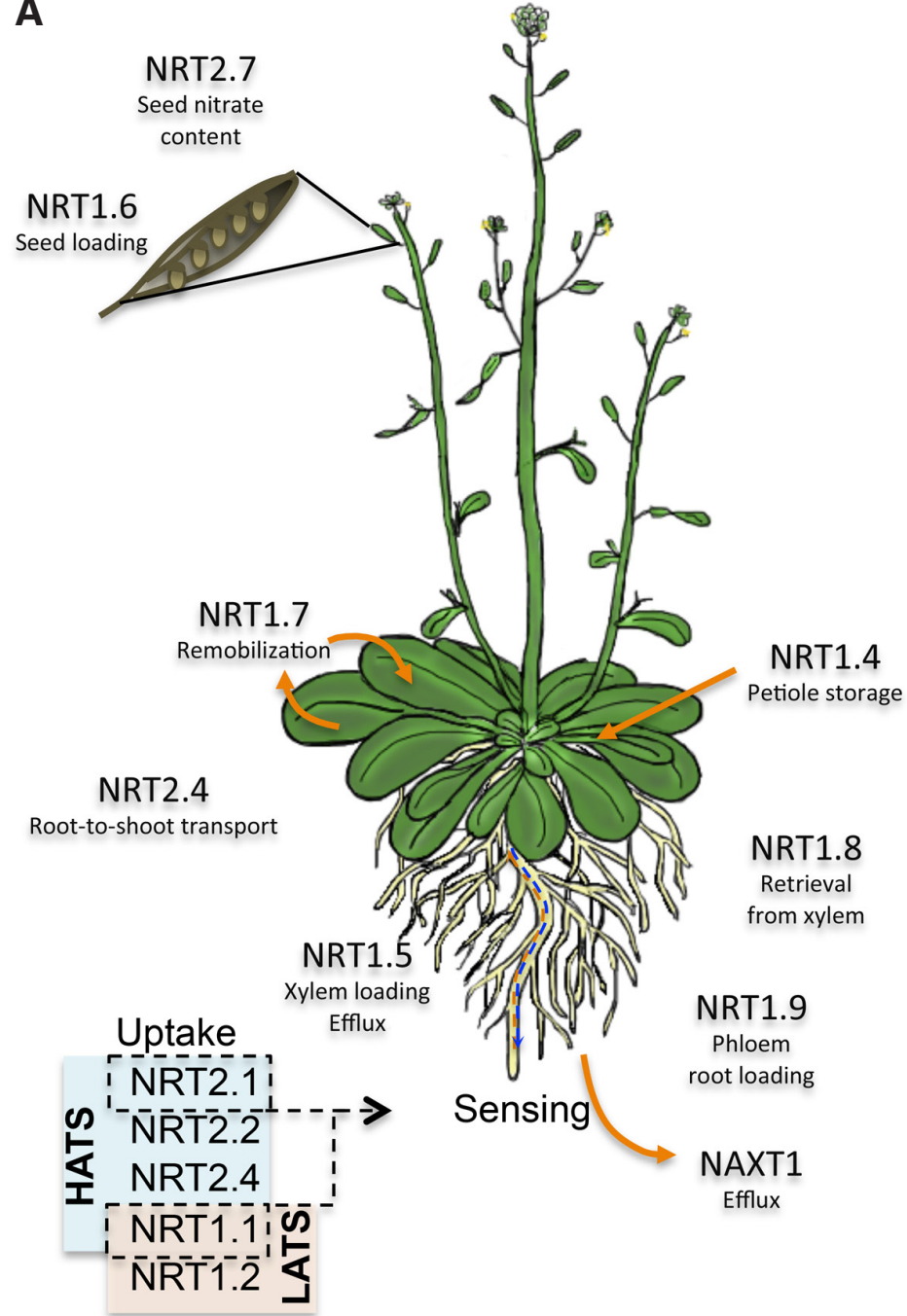

PROTEIN KINASE23 (CIPK23) (Fig. 1B). Phosphorylated and dephosphorylated NRT1.1 acts as a HATS and LATS, respectively (Bouguyon et al., 2012). Interestingly, these properties allow NRT1.1 to sense a wide range of $\mathrm{NO}_{3}$ - concentrations in the soil and switch between its transporting and signaling activities. In contrast to CIPK23, CIPK8 positively regulates the low-affinity phase of NRT1.1. Furthermore, NRT1.1 transceptor-dependent gene regulation is quite complex (Fig. 1B): it can up-regulate NRT2.1 in response to short-term $\mathrm{NO}_{3}$ - induction and down-regulate it under prolonged high $\mathrm{NO}_{3}^{-}$levels (Gojon et al., 2011).

NRT2.1 is the main component of inducible HATS in Arabidopsis roots, as demonstrated in nrt2.1 that lack up to $75 \%$ of the high-affinity $\mathrm{NO}_{3}-$ uptake activity. To be active, NRT2.1 forms a functional unit with NITRATE ACCESSORY PROTEIN2.1 (also called AtNRT3.1) that plays an important role in both constitutive and inducible HATS (Laugier et al., 2012). NRT2.1 is up-regulated by $\mathrm{NO}_{3}$-and sugars and down-regulated by $\mathrm{N}$ assimilation products (such as GIn) and cytokinin (CK) (Kiba et al., 2011).

B
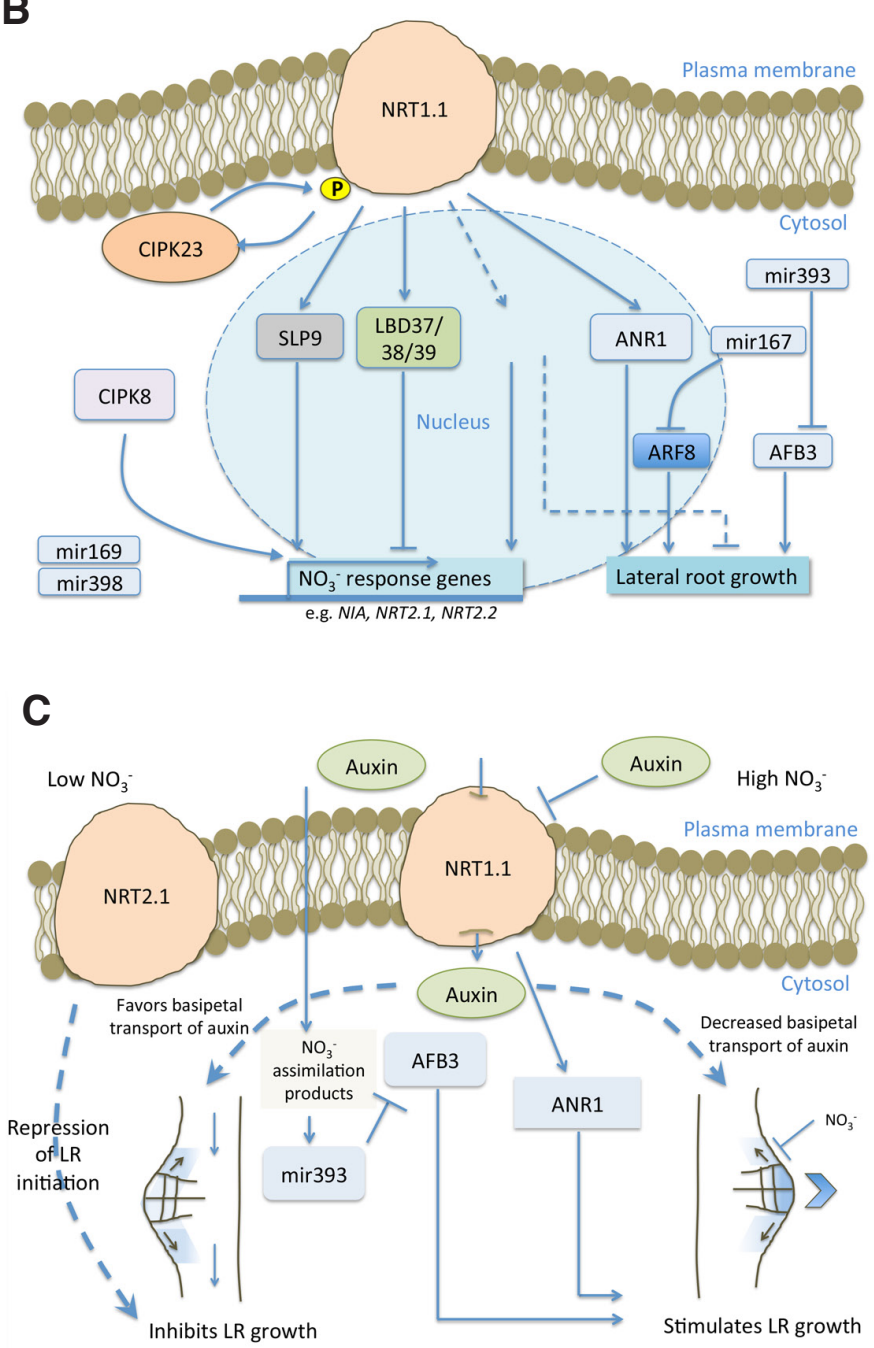

Fig. 1. Transporters and regulatory elements involved in nitrate metabolism. (A) Nitrate is taken up through the root system and allocated to different tissues by the concerted action of numerous transporters. NRT1.1 and NRT2.1 also sense the nitrate status in the environment and inside the plant. (B) Schematic representation of the signaling pathways that regulate the expression of nitrate-responsive genes. (C) Schematic representation of the signaling pathways specifically involved in changes in root architecture in response to nitrate. 
Assimilation of nitrogen through the NR-NiR-GS-GOGAT pathway

Once $\mathrm{NO}_{3}$-has entered the root, it can be directly assimilated in root cells or transported across the plasma membrane to different tissues. To be incorporated into organic molecules, such as amino acids, $\mathrm{NO}_{3}$ - is first converted in the cytoplasm into $\mathrm{NO}_{2}^{-}$by a nitrate reductase (NR), then into $\mathrm{NH}_{4}^{+}$by nitrite reductase (NiR) in both the cytoplasm and plastids, and, finally, the resulting $\mathrm{NH}_{4}^{+}$into amino acids (e.g. Gln and glutamate [Glu]) through the glutamine synthetase (GS)/glutamate syntase (glutamine-2-oxoglutarate aminotransferase (GOGAT) pathway.

Sugars play a central role in the coordination of carbon $(C)$ and $N$ metabolism because amino acid biosynthesis requires $\mathrm{C}$ skeletons. For instance, light and carbohydrates transcriptionally induce NRencoding genes, thus increasing $\mathrm{N}$ assimilation and amino acid biosynthesis when photosynthates are available. Recently, the mitochondrial folylpolyglutamate synthetase, encoded by DFC, has been involved in $\mathrm{N}$ assimilation through folate biosynthesis. Arabidopsis DFC-deficient mutants showed altered $\mathrm{N}$ utilization and a considerable reduction in lateral root (LR) initiation during early seedling development, a phenotype enhanced under low- $\mathrm{N}$ conditions (Jiang et al., 2013).

$\mathrm{N}$ is predominantly transported inside plants as $\mathrm{Gln}$, Glu, asparagine (Asn), aspartate (Asp), and, to a lesser extent, as $\mathrm{NO}_{3}^{-}$and $\mathrm{NH}_{4}^{+}$. This task is accomplished by the concerted action of LATS (NRT1.4-9) belonging to the NRT1/PTR family that play specific roles in plant development (Fig. 1A) (Wang et al., 2012). Two additional HATS, NRT2.4 in Arabidopsis and NRT2.3a in rice (Oryza sativa) have been recently involved in root-to-shoot $\mathrm{NO}_{3}{ }^{-}$transport under $\mathrm{N}$-limited conditions (Kiba et al., 2012; Tang et al., 2012) (Fig. 1A).

NRT1.1, CIPK23, and CIPK8 are well known to participate in the regulation of plant responses to low- $\mathrm{NO}_{3}$ - availability. However, because mutants affecting this signaling pathway still present specific responses to $\mathrm{NO}_{3}$ - deprivation, additional sensing systems (different to the NRT2.1-dependent one) might exist in plants that, together with some TFs, could combine at least two different low$\mathrm{NO}_{3}$-response-controlling signaling pathways (Fig. 1B,C). Recently, NODULE INCEPTION-LIKE PROTEIN7 (NLP7) has been reported as a novel TF involved in $\mathrm{NO}_{3}$ - signaling. Arabidopsis n/p7 mutants show a phenotype similar to that of $\mathrm{N}$-starved wild-type plants and a considerably reduced expression of $\mathrm{NO}_{2}{ }^{-}$transporters (NRT2.1 and NRT2.2) and NR-encoding genes (NIA1 and NIA2) after a short $\mathrm{N}$ stress followed by $\mathrm{NO}_{3}-$ resupply. The increased $\mathrm{LR}$ growth phenotype of $n / p 7$ plants hints at a possible role of NLP7 in root branching under $\mathrm{NO}_{3}$ - deficiency (Castaings etal., 2009). Additionally, three members of the TF LATERAL ORGAN BOUNDARY DOMAIN gene family (LBD37, LBD38, and LBD39) have been found to act as negative regulators of $\mathrm{NO}_{3}$-responsive genes (e.g. NRT2 and NIA genes) (Rubin et al., 2009) (Fig. 1B).

\section{Root architecture responses to nitrate availability}

Root system architecture responses to $\mathrm{NO}_{3}^{-}$availability are particularly interesting because $\mathrm{NO}_{3}{ }^{-}$has the capacity to induce two contrasting effects on root growth in several plant species: the inhibition of the root growth when $\mathrm{NO}_{3}{ }^{-}$is high and uniformly distributed in the media, and the stimulation of root growth by the direct contact with $\mathrm{NO}_{3}{ }^{-}$-rich patches. This was initially observed in Arabidopsis split-root experiments in which the application of different $\mathrm{N}$ sources to one side of the split-root system caused a 2- to 4-fold increase in LR length (McAllister et al., 2012). Although some elements regulating these responses have been characterized at the molecular level, many remain to be uncovered. ARABIDOPSIS NITRATE-REGULATED1 (ANR1), a MADS-box TF normally expressed in root tips of primary root (PR) and LR, and NRT1.1, have been identified as key components in the signal transduction pathway regulating $\mathrm{NO}_{3}^{-}$-inducible root growth (Remans etal., 2006a) (Fig. 1C). Arabidopsis nrt1.1 mutant displays alteration in PR and LR development, independently of $\mathrm{N}$ uptake and availability. The nrt1.1 phenotype has been associated with a decrease in ANR1.1 transcript abundance, placing NRT1.1 upstream of ANR1.1. Enhancer trap and dexamethasone-inducible overexpressing lines confirmed that $A N R 1$ positively regulates LR initiation and growth, being more responsive in the presence of $\mathrm{NO}_{3}^{-}$(Gan et al., 2012). In Arabidopsis, nrt2.1 mutants have decreased LR initiation, independently of its transport activity, suggesting a role for NRT2.1 in the control of root development (Remans et al., 2006b). In fact, increasing evidence demonstrates that NRT2.1 acts as a sensor or signal transducer in an $\mathrm{N}$-dependent LR growth-regulating pathway (Fig. 1C) (Gojon et al., 2011).

A role for auxin on root branching in response to $\mathrm{NO}_{3}$ - availability has also been uncovered. For instance, NRT1.1 not only senses $\mathrm{NO}_{3}-$ responses, but also possibly facilitates auxin transport to promote LR growth under low-NO ${ }_{3}^{-}$conditions (Fig. 1C) (Remans et al., 2006a; Krouk et al., 2010). Additionally, cell-specific transcript profiling in response to $\mathrm{NO}_{3}^{-}$allowed the identification of the miR167/AUXIN RESPONSE FACTOR8 regulatory module as an important component in regulating the ratio between initiating and emerging LRs in Arabidopsis (Gifford et al., 2008). Recently, the AUXIN SIGNALING F-BOX 3 , an auxin receptor induced by $\mathrm{NO}_{3}{ }^{-}$in roots, was reported to be down-regulated by $\mathrm{N}$ - metabolites due the induction of miR393, modifiying auxin perception and, in turn, affecting PR and LR growth (Fig. 1C) (Vidal et al., 2010). Because $\mathrm{CK}$ levels strongly correlate with $\mathrm{N}$ - status, a direct role of this hormone in regulating root architecture has also been proposed (Kiba et al., 2011).

Crosstalk between auxin, abscisic acid, and CK signaling pathways has also been involved in coordinating the requirement and acquisition of $\mathrm{N}$ and their effects on root branching (Fig. 1C). For instance, in Arabidopsis, NRT1.1 regulates the expression in roots of AtIPT3 (ADENOSINEPHOSPHATASE-ISOPENTENYLTRANSFERASE), a gene involved in CK biosynthesis. However, it has been shown that when exogenously applied, CKs repress the expression of some $\mathrm{NO}_{3}, \mathrm{NH}_{4}{ }^{+}$, and amino acid transporters, especially those expressed in roots (for a detailed review of hormonal control of $\mathrm{N}$ metabolism, see Kiba et al., 2011).

\section{Engineering nitrogen use efficiency}

As mentioned previously, the use of $\mathrm{N}$ - fertilizers has resulted in significant increases in crop yield. However, this has been accompanied by an inevitable negative environmental impact, because only $30 \%$ to $50 \%$ of the applied $\mathrm{N}$ is used by crop plants, whereas with the remainder is lost by leaching, run-off, volatilization, or microbial activity. This situation has received great attention for many years and numerous research groups are attempting to identify genes that improve Nitrogen Use Efficiency (NUE) in plants. Although many definitions and evaluation methods have been proposed, NUE has been defined as the yield of grain per unit of $\mathrm{N}$ available in the soil (natural or applied).

The efficiency issue is being tackled by trying to identify genes 
involved in $\mathrm{N}$ uptake and assimilation that have the potential to improve NUE. Extensive experiments with several plant species, including Arabidopsis, Vicia narbonensis (purple broad vetch), Pisum sativum (pea), Brassica napus (canola), Nicotiana tabacum (tobacco), rice, Zea mays (maize), and Glycine max (soybean), have allowed the identification of specific genes involved in amino acid biosynthesis, $\mathrm{C} / \mathrm{N}$ homeostasis, and the regulation of $\mathrm{N}$ uptake, translocation, and assimilation, as candidate genes to improve NUE (for a detailed review, ision see Xu et al., 2012). However, in many cases, overexpression of these genes in many instances did not result in a direct effect on this trait. In the following paragraphs, some attempts to improve NUE are discussed.

Candidate genes involved in transport, translocation, and remobilization of nitrogen

$\mathrm{N}$ uptake is one of the most critical NUE components under Nlimiting conditions. Although $\mathrm{NO}_{3}$-transporters, such as NRT1.1 and NRT2.1, are the first components of the $\mathrm{NO}_{3}{ }^{-}$assimilation pathway in the root, only few studies have been carried out to characterize the effect of their overexpression on plant growth and development. Although overexpression of the high-affinity NRT2.1 (NpNRT2.1) transporter in tobacco (Nicotiana. plumbaginifolia) led to an increase in $\mathrm{NO}_{3}^{-}$uptake under low- $\mathrm{NO}_{3}{ }^{-}$conditions, no net improvement in NUE was observed (Quilleré et al., 1994).

Overexpression of other transporters/translocators involved in $\mathrm{N}$ homeostasis has been reported to have effect on NUE. Accumulation of storage protein (e.g. globulins and, albumins) in seeds has been strongly associated with $\mathrm{N}$ availability and partitioning of $\mathrm{N}$ - assimilates in several plant species. Therefore, improving amino acid uptake into the embryo could improve NUE. This was demonstrated by overexpression of the Vicia faba (fava bean) AMINO ACID PERMEASE1 (VfAAP1) gene in $V$. narbonensis and pea that increased accumulation of storage proteins, particularly globulins, and of some amino acids such as Asn, Asp, Glu, and GIn in the seeds. Interestingly, seed from VfAAP1-overexpressing pea lines presented 20,43 and $5 \%$ higher N, globulin, and weight, respectively, than those of control plants (Rolletscheck et al., 2005). In rice, overexpression of the endogenous EARLY NODULIN93-1 (ENOD93-1) gene, which is potentially involved in amino acids transport, resulted in increased shoot dry biomass and the concentrations of total amino acids and total $\mathrm{N}$ in roots, especially under $\mathrm{N}$ stress. Moreover, although the number of tiller produced by ENOD93-1-overexpressing and untransformed plants was similar, transgenic plants exhibited a 10\%-20\% higher number of spikes and spikelets, which was reflected in an enhanced seed yield under both limiting and high- $\mathrm{N}$ conditions (Bi et al., 2009). Additionally, data reported in some patents suggest that overexpression of an improved yeast nitrate transporter in maize results in an increased $\mathrm{NO}_{3}{ }^{-}$uptake under field conditions (McAllister et al., 2012).

\section{Modulation of NR and NiR enzymes to improve nitrogen use}

As stated above, $\mathrm{NO}_{3}-$ assimilation is controlled by the concerted action of several enzymes, such as NR and NiR. These enzymes are important regulatory checkpoints to be considered for improving NUE. However, overexpression of the tobacco NR-encoding genes NIA1 and NIA2 in different plants (e.g. Solanum tuberosum [potato], Lactuca sativa [lettuce], and N. plumbaginifolia) showed no NUE-phenotype associated under $\mathrm{N}$-limiting conditions. Accordingly, overproduction of NR in N. plumbaginifoliaresulted in reduced
$\mathrm{NO}_{3}{ }^{-}$levels in leaves, corresponding to an increase in foliar Gln and malate accumulation (Good et al., 2004). When the tobacco NIA2 gene was overexpressed in potato, $\mathrm{NO}_{3}^{-}$levels in the tubers were lower than those in control plants and without effect on yield or tuber number (Djennane et al., 2002). The lack of positive effects of overexpression of genes encoding NR and NiR has been associated with a tight regulation at the translational and posttranslational levels. However, several patents protect the use of NR-encoding genes from the red algae Porphyra perforata and $P$. yezoensis, which overexpression increased yield in maize under $\mathrm{N}$-limiting conditions (Good et al., 2004). These results suggest that more detailed studies are still necessary to unravel the mechanisms that regulate the expression of $N R$ and NiRgenes at the transcriptional and posttranscriptional levels and, more importantly, that sources of NR- and NiR-encoding genes from organisms other than plants must be considered.

\section{Potential target genes from the GS-GOGAT pathway}

In higher plants, GS and GOGAT play key roles in $\mathrm{NH}_{4}^{+}$assimilation. $\mathrm{GS}$ is the rate-limiting enzyme in controlling $\mathrm{N}$ assimilation to support plant growth and productivity because it catalyzes the major step that converts $\mathrm{N}$ into organic compounds. The two GS isoforms, located in the cytosol of phloem companion cells (GS1) and in the stroma of chloroplast (GS2), have essential roles in the assimilation and recycling of $\mathrm{NH}_{4}{ }^{+}$. GOGAT also has a central role in $\mathrm{N}$ assimilation and, as GS, is present in two isoforms in leaves: a ferredoxin-dependent GOGAT (Fd-GOGAT), exclusively present in the chloroplasts, and a NAD-dependent GOGAT (NADH-GOGAT), preferentially located in vascular bundles of unexpanded leaves. Numerous attempts have been made to determine the specific roles of GS/GOGAT genes on plant development. The study of $g s$-mutants in maize, for example, has revealed that GS has a pivotal role in grain filling, determining kernel size, and yield (references in Good et al., 2004). Therefore, changing the expression of GS genes as well as GS activity could potentially affect NUE.

Many experiments have been carried out to overexpress both cytosolic and plastidic GS isoforms in different plant species. The results obtained are controversial: some authors report positive effects on plant growth and protein content, whereas others have been unable to show a specific phenotype or increase in GS activity and none showed a direct effect on NUE. Overexpressionng a Medicago sativa (alfalfa) GS1 gene in tobacco resulted in $40 \%$ more protein per area and a higher total leaf GS activity than those of wild-type plants, but only changes in free $\mathrm{NH}_{3}$ and amino acid levels were observed in transgenic maize plants overexpressing a cytosolic GS1 (McAllister et al., 2012). Although plants with enhanced GS activity in roots were obtained by the root-specific expression of the GS15 gene of soybean in pea, biomass and $\mathrm{N}$ accumulation in the studied transgenic lines varied widely among $N$ treatments and $G S$ activity (Fei et al., 2006). Leaf-specific overexpression of GS2 in tobacco stimulated growth rate, amino acid accumulation (2.5-fold Glu and 2.3-fold GIn), and seed biomass, but the amount of protein per unit of fresh weight was unaltered (Migge et al., 2000). The GS activity in transgenic lines with 15- and 18-fold higher transcript levels was only 2- to 2.3-fold higher than in control plants, evidencing a posttranscriptional control of GS2.

In the case of GOGAT, several reports have demonstrated its importance in grain production because, when suppressed, grain yield in rice, Triticum sp. (wheat), Sorghum bicolor (sorghum) and 
maize is drastically reduced. For instance, a nadg-gogat1 knockout mutant in rice showed a reduced number of panicles and spikelets per plant, causing a decrease in total yield and biomass (Tamura et al., 2010). Recently, cosuppression of both Fd-GOGAT and NADHGOGAT isoforms in rice drastically decreased tiller number, total shoot dry weight, and yield (Lu et al., 2011). In rice, overexpression of NADH-GOGAT has been associated with an enhanced grain filling (Yamaya et al., 2002) and, when overexpressed under its own promoter, grain weight was $80 \%$ increased, whereas overexpression of an alfalfa NADH-GOGAT in tobacco enhanced the $\mathrm{C}$ and $\mathrm{N}$ contents in shoots and roots (Good et al., 2004; McAllister et al., 2012). The study of the combined effects of GS and GOGAT overexpression with other genes involved in $\mathrm{N}$ metabolism could provide more consistent improvements in NUE.

In two rice cultivars with different GS2 activities, the ability to recycle and reassimilate $\mathrm{NH}_{3}$ within the plant was better in the cultivar with high GS activity (Akenohoshi) than that of the cultivar with low GS activity (Kasalath), because less $\mathrm{NH}_{3}$ is lost to the environment (Kumagai et al., 2011). These data suggest that a diversity of tools must be considered to analyze the effects of assimilative enzymes on NUE and that the reduced $\mathrm{NH}_{3}$ emission in crops is an additional target trait to improve NUE.

Genetic modifications involving transcription factors and other regulatory elements

TF candidates. The use of signaling and regulatory proteins, such as TFs, is a promising approach to modify plant metabolism for NUE improvement. For instance, ANR1 overexpression induces LR initiation and elongation in Arabidopsis (Gan et al., 2012). The manipulation of other genes, such as the overexpression of a maize FERREDOXIN-NADP ${ }^{+}$REDUCTASE gene, enhanced root growth, ear size, and seed weight in transgenic maize, soybean, and rice (McAllister et al., 2012). The increase in productivity of ANR1-overexpressing plants could be due to an increase in $\mathrm{N}$ uptake resulting from an enhanced exploratory capacity of the root system, which is one of the critical steps that limit the efficient use of applied $\mathrm{N}$ fertilizers. However, increased $\mathrm{N}$ uptake rates do not necessarily imply a higher assimilatory capacity, which would depend on the competitive nature of the plant itself. Therefore, an increased $\mathrm{N}$ uptake capacity combined with genes affecting seed production will probably be needed. For instance, the reduced expression of CYTOKININ OXIDASE2 gene in rice, identified as quantitative trait locus Gn1a, increases the number of reproductive organs, improving grain yield (Ashikari et al., 2005).

Overproduction of the DNA-binding with One Finger1 (Dof1) TF appears to enhance $\mathrm{N}$ uptake and assimilation under low- $\mathrm{N}$ conditions. Dof1 is a key activator for multiple genes associated with organic acid metabolism. Maize Dof1-overexpression in Arabidopsis revealed improved growth and increased amino acid (GIn and Glu) and total $\mathrm{N}$ contents under low- $\mathrm{N}$ conditions (Yanagisawa et al., 2004). Recently, ZmDof1-overexpressing experiments in rice showed enhanced $\mathrm{N}$ and $\mathrm{C}$ accumulation and photosynthesis rates in transgenic rice plants under $\mathrm{N}$-limiting conditions. $\mathrm{N}$ accumulation occurred particularly in roots that had also a higher biomass than the control plants (Kurai et al., 2011).

Candidate genes involved in amino acid metabolism. Due to the importance of Gln and Glu as starting materials for the synthesis of other amino acids and nucleotides, the overexpression of enzymes involved in $\mathrm{N}$ assimilation have been assayed. One of these cases is the expression of the alanine aminotransferase-encoding gene (AlaAT) from Hordeum vulgare (barley) in canola and rice. AlaAT is an enzyme involved in stress and hypoxia recovery in plants. Transgenic lines overexpressing AlaAT under the canola rootspecific btg26 promoter displayed an increase in biomass and seed yield under $\mathrm{N}$-limiting field conditions. In field trials with suboptimal $\mathrm{N}$ fertilization (56 kg.ha-1), the seed yield of transgenic plants was $42.3 \%$ higher than that of the wild-type control plants, whereas at a rate of $168 \mathrm{~kg} \cdot \mathrm{ha}^{-1}$, the seed yield increased by $32.7 \%$ (Good et al., 2007). However, overexpression of AlaAT in Arabiodopsis did not result in a consistent phenotype and its positive effect in improving NUE was tissue specific.

Overexpression of the glutamate dehydrogenase $\mathrm{A}(\mathrm{gdh} A)$ gene from Escherichia coli in tobacco resulted in a 10\% increase in dry weight under field conditions with a regimen of $125 \mathrm{~kg} \cdot \mathrm{ha}^{-1}$ of applied N (Ameziane et al., 2000). Interestingly, when overexpressed in maize, the same enzyme induced an increased germination and grain production when plants were grown under water stress.

In higher plants, $\mathrm{N}$ is assimilated in Asn and Glu from GIn and Asp via asparagine synthetase (AS) that is encoded in Arabidopsis by a small gene family ( $A S N 1, A S N 2$, and $A S N 3$ ). Because Asn plays a key role in allocating $\mathrm{N}$ between source and sink organs as $\mathrm{N}$ storage compound, analysis of the effects of $A S N$ overexpression is important. ASN1-overexpressing Arabidopsis plants show an enhanced tolerance to $\mathrm{N}$-limiting conditions and an increased content of soluble and total proteins in seeds, as reflected in an increased seed weight. In addition, an increase in allocation of free amino acids (mainly Asn) to flowers and siliques has been observed (Lam et al., 2003). Interestingly, pathogen resistance is also conferred by overexpression of ASN in Arabidopsis (Hwang et al., 2011).

In addition, overexpression of the $E$. coli AS-encoding gene $(A S-A)$ in lettuce resulted in early seed germination, early development of leaves and early bolting and flowering time when compared with control plants. Additional determinations showed that in $A S$ - $A$-overexpressing lines, leaf protein content and dry weight were 1.2- to 1.4-fold and 1.3-fold higher, respectively, than those in wild-type plants (Giannino et al., 2008). Overexpression of this enzyme in other leafy crops needs to be assessed to study a possible positive effect on NUE.

Aspartate amino transferase (AspAT), an enzyme involved in Asp and 2-oxogluatarate synthesis from Glu and oxaloacetate, and AlaAT have been proposed as main players in grain filling. However, overexpression of $A s p A T$ resulted in increased amino acid and protein contents in seeds, but not in improved seed yield or biomass under low-N or high-N conditions (McAllister et al., 2012). Further studies of these enzymes in crop plants as well as field trials are needed to determine whether they can be used to enhance NUE in cereals.

Candidate genes involved in photosynthesis and carbon metabolism. It has been well documented that ribulose-1,5-biphosphate carboxylase oxidase (RuBisCO) and phosphoenolpyruvate carboxylase (PEPC) are key players in $\mathrm{C}$ fixation and $\mathrm{N}$ storage as crosstalk points between $\mathrm{C}$ and $\mathrm{N}$ metabolism. Overexpressing RuBisCO theoretically represents a potential increase in photosynthesis, which is an ideal trait for crop improvement. In rice, $\mathrm{RuBisCO}$ 
overexpression experiments resulted in an increase in RuBisCO to leaf $\mathrm{N}$ ratio, but the photosynthesis rate did not change. Similar results were obtained by overexpressing $P E P c$ in tobacco and rice. However, gene shuffling of the RuBisCO large subunit apparently resulted in enhanced RuBisCO activity in maize, thus influencing NUE (McAllister et al., 2012).

The manipulation of other proteins involved in $\mathrm{N}$ homeostasis has positively affected NUE. The Arabidopsis SUGARTRANSPORT PROTEIN13 (STP-13) is active in hexose transport in sink tissues and is regulated by a $\mathrm{NO}_{3}{ }^{-}$-inducible GATA TF. In Arabidopsis STP13-overexpressing plants, glucose uptake rate and Naccumulation were higher than in control plants and more biomass was produced under N-limiting conditions (Schofield et al., 2009). The study of this type of transporters will help to understand the interactions between $\mathrm{C}$ and $\mathrm{N}$ metabolism and demonstrate that NUE may be improved by increasing $\mathrm{C}$ availability.

\section{Super crops for low-phosphate soils: a dream or short-term reality?}

Although the content of total organic $\mathrm{P}$ and inorganic $(\mathrm{Pi})$ in the earth crust is high, the availability of orthophosphates $\left(\mathrm{H}_{2} \mathrm{PO}_{4}^{-}\right.$and $\mathrm{HPO}_{4}{ }^{2-}$ ), the only chemical form that can be acquired and assimilated by plants, is low and heterogeneous in almost all natural and agricultural ecosystems. Pi availability strongly depends on several factors, such as soil $\mathrm{pH}$, cation presence, and its rapid conversion by soil microorganisms into organic forms that are not directly available for plant uptake (Alatorre-Cobos et al., 2009). The negative effect of these factors is clearly noticeable in the high amounts of $\mathrm{Pi}$ fertilizers used each year. Of particular importance is that only approximately $20 \%$ to $30 \%$ of the $P$ fertilizers applied is effectively exploited by cultivated plants. Therefore, $\mathrm{P}$ represents one of the major constraints to increase crop productivity in arable lands worldwide.

During land plant evolution, primitive aquatic plants, which came from a mineral-rich aquatic world, had to cope with low-Pi availability in the newly colonized terrestrial habitats. This adaptation involved the acquisition of complex and orchestrated strategies to survive and reproduce under Pi-limiting conditions. Currently, forward and reverse genetics approaches combined with analyses of whole transcriptomes, obtained by high-throughput sequencing technologies, allow the identification of master controllers of the different signaling pathways that modulate plant responses to $\mathrm{Pi}$ deficiency. Genes involved in Pi uptake, translocation, and recycling have been characterized and their possible roles in enhancing Phosphate Use Efficiency (PUE) have been evaluated. In the following sections, we will describe some of the genetic modifications that are aimed toward increasing PUE and are potentially useful for agronomically important crops.

\section{Pi signaling pathway components}

$\mathrm{Pi}$ uptake from the rhizosphere is a function carried out by proton $\left(\mathrm{H}^{+}\right) / \mathrm{Pi}$ symporters, simply called Pi transporters. To date, four gene families of Pi transporters (PHT1, PHT2, PHT3, and PHT4) have been identified in Arabidopsis and their respective orthologs have been found in other plant species. Special attention has been given to the Arabidopsis PHT1 gene family that includes nine members encoding high-affinity $\mathrm{Pi}$ carriers that are mainly expressed in root epidermal cells and are highly responsive to $\mathrm{Pi}$ deficiency. The contribution of these carriers to Pi acquisition has been determined with null mutants and gene overexpression approaches in Arabidopsis and rice. The first plant Pi transporter was identified by overexpression of the Arabidopsis AtPT1/AtPHT1;1. Tobacco cells overexpressing AtPHT1;1, produced 1.5-fold higher biomass than control cells when grown under Pi-limiting conditions (Mitsukawa et al., 1997). Recently, a role in tolerance to low-Pi availability of AtPHT1;9 was observed in Arabidopsis AtPHT1;9overexpressing lines, in which $20 \%$ to $30 \%$ more shoot fresh weight was produced than in wild-type plants under $\mathrm{Pi}$-limiting conditions (Remy et al., 2012). In rice, overexpression of OsPT1 not only results in a two-fold higher $\mathrm{Pi}$ content than in wild-type plants, but also in a higher number of tillers per plant, independent of the $\mathrm{Pi}$ fertilization regimen (Seo et al., 2008). In contrast, barley plants with an enhanced expression of HORvu;Pht1;1 (HvPT1) showed no differences in dry weight and total $P$ content when compared to control plants (Rae et al., 2004). Thus, although a positive correlation between enhanced expression of PHTs and increased Pi content has been reported, it is not always observed, implying that a tight control operates at different levels (transcriptional, translational, and metabolic rearrangements) to maintain plant $\mathrm{Pi}$ homeostasis.

In general, overexpression of PHTgenes moderately increases $\mathrm{Pi}$ content and biomass accumulation, whereas the constitutive expression of regulatory elements, such as TFs, microRNAs, signaling intermediates, or some TF activity modifiers, apparently increases $\mathrm{Pi}$ accumulation in plant tissues (Fig. 2). In Arabidopsis, overexpression of PHOSPHATE STARVATION RESPONSE1 (PHR1), a master TF controlling a large subset of $\mathrm{Pi}$ stressresponsive genes, including $P H T$ genes, resulted in a $2.5-$ and 4-fold increase in shoot $\mathrm{Pi}$ accumulation, under $\mathrm{Pi}$-sufficient and Pi-stress conditions, respectively (Nilsson et al., 2007). Such increases have been associated directly with increased transcript levels of AtPHT1;7, AtPHT1;8, and AtPHT1;9, confirming that $\mathrm{Pi}$ acquisition is a concerted action between several transporters and that their individual overexpression might not be sufficient to have a significant impact on $\mathrm{Pi}$ content and plant growth. In rice and canola, overexpression of $P H R 1$ orthologs had similar effects on $\mathrm{Pi}$ accumulation and PHT expression levels (Zhou et al., 2008; Ren et al., 2012). In PHR2-overexpressing rice plants, increased $\mathrm{Pi}$ content was associated with changes in root system architecture (longer PR and LRs) (Zhou et al., 2008). Interestingly, in null mutants of the AtSIZ1 (a positive regulator of PHR1 activity by sumoylation) gene, a root phenotype similar to that described for PHR2-overexpressing plants was associated with changes in auxin accumulation (Miura et al., 2011). Although SIZ1 and PHR1 are components of the same signaling pathway that regulate many responses to $\mathrm{Pi}$ deficiency, these molecular controllers might play opposite roles on root development (Miura et al., 2011).

Improved performance under Pi limiting conditions has also been reported in transgenic plants in which other TFs, that participate in the control of the plant responses to $\mathrm{Pi}$ deprivation, are expressed constitutively (Dai et al., 2012). In rice, OsMYB2P-1 encodes a novel R2R3 MYB TF, of which the expression is induced in roots, stems, and leaves by Pi starvation. Under Pi-limiting conditions, OsMYB2P-1-overexpressing rice plants show an enhanced tolerance to low $\mathrm{Pi}$, as reflected in a $24 \%$ and $30 \%$ higher shoot and root dry weight, respectively, than those of control plants. Such increase in biomass production in OsMYB2P-1-overexpressing plants was positively correlated with enhanced Pi content, espe- 
cially in roots. However, under Pi-sufficient conditions, OsMYB2P1-overexpressing rice plants showed a $50 \%$ decrease in shoot and root growth associated with an increased Pi content. As observed for PHR1 overexpression, constitutive expression of OsMYB2P-1 also up-regulates the expression of PHT genes (Dai et al., 2012).

Modulator functions on $\mathrm{Pi}$ homeostasis are also known for other signaling components located downstream of TFs. SPX proteins have been described in yeast and in humans as proteins harboring domains involved in Pi perception, signaling, and transduction. In Arabidopsis and rice, analyses of SPX-RNAi and $S P X$-overexpressing lines indicate that SPX proteins negatively modulate the expression of genes involved in the uptake, allocation, and remobilization of Pi (Wang et al., 2009a). As SPX genes play an important role in $\mathrm{Pi}$ homeostasis in plants, they represent a potential target to produce plants with improved PUE.

Although large sets of Pi-responsive TFs have been identified in massive transcriptomic analyses, new $P$ signaling networks, different from those controlled by SIZ1/PHR1, have been poorly described. Characterization of new genetic controllers for Pi homeostasis and a better understanding of Pi signaling networks will provide new opportunities to generate plants with an enhanced $\mathrm{Pi}$ use, especially under low-Pi availability conditions.

\section{Biotechnological approaches to improve phosphate uptake and PUE}

Piacquisition capacity in conjunction with the internal PUE are the two major parameters influencing PUE index. For the last 10 to 15 years, crops with a high PUE have been obtained by exploring the natural variation among crop genotypes or by modifying the expression of genes directly involved in $\mathrm{Pi}$ uptake or those considered as master regulators of $\mathrm{Pi}$ homeostasis in plants (e.g. Pi transporters, TFs, signaling intermediates, and traffic facilitators). Moreover, the use of bacterial genes involved in the metabolism of nonconventional $P$ sources has provided interesting results. Among the efforts to improve the PUE, three attempts are generally considered promising if implemented in important crops and the field trials are successful: the use of phythases to metabolize phytate, the use of citrate synthases to overproduce citrate, and the use of phosphite dehydrogenase to use phosphite (Phi) instead of $\mathrm{Pi}$ as fertilizers (Fig. 2,3). Below, these approaches and their implications will be discussed.

\section{Releasing phosphate for surviving: a role for} phytases and organic acids

The rapid fixation of $\mathrm{Pi}$ into the soil by cation interaction and its quick conversion into organic forms (not readily available for plant uptake) by microbial activity are probably the main causes of low Pi availability in natural soils. Therefore, for plant uptake, $\mathrm{Pi}$ must first be released from insoluble compounds or organic forms present in the soil. In response to $\mathrm{Pi}$ deficiency, the root system of several plant species, such as canola, Lupinus albus (white lupin) and the Proteaceae plant family, shows an enhanced exudation of organic acids (OAs; such as citrate), favoring Pi solubilization and enhancing $P$ uptake. This response is positively controlled at transcriptional and posttranscriptional level in monocotyledonous and dicotyledonus plants (Ryan et al., 2001). OAs are low-molecular weight carbon compounds harboring one or more carboxyl groups and are intermediates (e.g. citrate, malate, and fumarate) in the tricarboxilic acid cycle of living cells. In soils, depending on their dissociation properties and number of carboxyl groups, OAs can bind different cations, such as aluminum $\left(\mathrm{Al}^{3+}\right)$, iron $\left(\mathrm{Fe}^{3+}\right)$, and calcium $\left(\mathrm{Ca}^{2+}\right)$, ameliorating the negative effects of these cations on plant nutrition.

The initial attempt to improve $\mathrm{Pi}$ acquisition in plants was the enhancement of the OA production and exudation with the aim to overcome $\mathrm{Al}^{3+}$ toxicity in acidic soils and to remobilize $\mathrm{Pi}$ from calcium phosphates in alkaline soils. In 1997, tobacco and Carica papaya (papaya) transgenic plants expressing a bacterial citrate synthase gene were produced (De la Fuente et al., 1997). These transgenic plants had an enhanced capacity to acquire Pi from insoluble-P sources. Under different Pi regimens, the transgenic tobacco plants accumulated more dry weight in shoots and fruits (15\% and 23 to $35 \%$, respectively) than control plants, corresponding to an increased total P content in shoots (30\% to 40\%) (LópezBucio et al., 2000). Although these initial results were controversial, several independent studies have confirmed a positive correlation between overexpression of genes encoding enzymes involved in OA biosynthesis and an improved plant growth in soils with low $\mathrm{Pi}$ availability and/or in the presence of toxic $\mathrm{Al}^{3+}$ concentrations (Ryan et al., 2011).

In the last decade, research on $\mathrm{Al}^{3+}$ tolerance mechanisms in plants has expanded our knowledge on new molecular players implicated in the release of OAs by roots into the rhizosphere. Recently, MULTRIDUG AND TOXIN COMPOUND EXTRUSION (MATE) genes that encode OA transporters have been identified

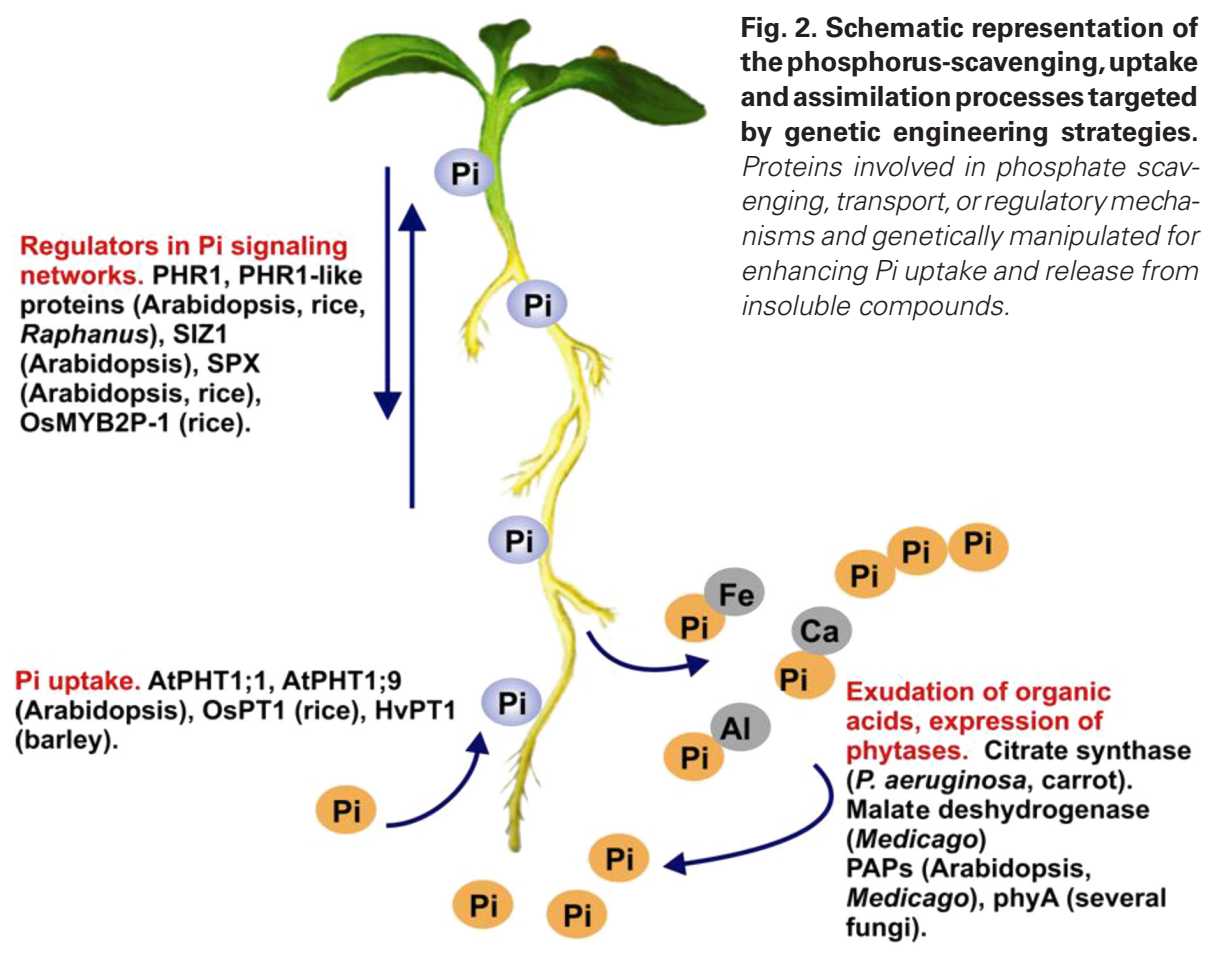


(Ryan et al., 2011), of which some are root specific and induced by $\mathrm{Pi}$ deficiency or toxic $\mathrm{Al}^{3+}$ concentration. The role of MATE proteins in $\mathrm{Al}^{3+}$ tolerance was demonstrated by heterologous expression and knockout mutant analyses, but their possible function in $\mathrm{Pi}$ acquisition still remains to be uncovered (Ryan et al., 2011). The effectiveness of enhanced OAbiosynthesis and OA efflux transporters to confer an enhanced $\mathrm{Pi}$ uptake or $\mathrm{Al}^{3+}$ tolerance remains to be demonstrated under field conditions and to be agronomically relevant.

Enhancement of the Pi-scavenging capacity of plants, especially during Pi starvation, has been tested via the expression of genes encoding enzymes that directly hydrolyze organic Pi forms that cannot be taken up directly by plant roots. Special attention has been paid to hydrolytic enzymes that can liberate $\mathrm{Pi}$ from phytate (myoinositol 1,2,3,4,5,6-hexakisphosphate), the predominant organic form of $\mathrm{P}$ accumulated by animals and plants. These enzymes are collectively called phytases and are classified into four groups according to their catalytic properties: (i) histidine acid phosphatases (HAPs), (ii) purple acid phosphatases (PAPs), (iii) Cys phosphatases, and (iv) $\beta$-propeller phytases (BPPs) (BrinchPedersen et al., 2002; Ma et al., 2009).

The biotechnological impact of phythase secretion into the soil on Pi plant nutrition has been evaluated by constitutive or rootspecific expression of chimeric versions of phytase genes harboring extracellular targeting sequences. This strategy has been found to be effective for several plant species (e.g. Arabidopsis, Trifolium subterraneum [subterranean clover], potato, soybean, canola, rice, wheat, and tobacco) that were capable of growing in media supplied with phytate as the sole P source (Brinch-Pedersen et al., 2002; George et al., 2005). For instance, under in vitro conditions, the $\mathrm{Pi}$ content of transgenic phytase A-overexpressing tobacco plants grown with phytate as sole $\mathrm{P}$ source was 3-fold higher than that of control plants. However, the capacity of these transgenic plants to use phytate as a $\mathrm{P}$ source was reduced in natural low-Pi soils (George et al., 2005).

In addition, canola and soybean plants expressing phytases (of HAP and BPP type) from several sources (e.g. fungi, bacilli, and yeast) have also been generated to evaluated their phytate-hydrolysing capacity in seeds, in which phytate accounts for $60 \%-80 \%$ of the total $P$, to improve nutrition of monogastric animals. When broilers and piglets were fed with these phytase-expressing seeds, significant increases in body-weight gain and gain-feed ratios were observed without adverse effects in liver, kidney, or bone tissues, when compared to control diets. These data suggest that expression of phytases increases the availability of the $\mathrm{Pi}$ contained in seeds for animal nutrition (Brinch-Pedersen et al., 2002).

The presence of PAPs has been reported in several plants species, usually as Pi-starvation responsive genes. In Arabidopsis, a large family for PAPs with at least 29 genes has been identified, of which only a few members encode enzymes with phytase activity. Heterologous expression of the PAP-encoding genes PAP15 (from Arabidopsis) and PAP1 (from Medicago truncatula [barrel medic]) in soybean and Trifoliumsp. (clover), respectively, showed a positive correlation between an enhanced phytase activity and a increase in dry weight and total $\mathrm{P}$ content when phytate was supplied as sole P source (Xiao et al., 2006; Wang et al., 2009b). Further characterization of the AtPAP15-overexpressing soybean plants showed that the numbers of pods and seeds per plant were higher than those of nontransformed controls (Wang et al., 2009b).
This increased productivity was observed even when plants were grown in natural acidic soils, but has not been observed for other HAP-overexpressing plants.

The relatively modest increase in $\mathrm{Pi}$ acquisition exhibited by phytase-overexpressing plants grown under natural soil conditions has been attributed to several factors, such as low phytase activity, nonspecific substrates, and low stability in the soil of the secreted protein. However, the importance of phytate availability has been largely ignored. In nature, phytate accumulates in the soil as a mixture with cations (usually $\mathrm{K}^{+}, \mathrm{Ca}^{2+}, \mathrm{Mg}^{2+}$, or $\mathrm{Zn}^{2+}$ ) known as phytin, which is transferred to the soil via plant and animal wastes. Engineered phytases to be secreted into the rhizosphere or those naturally associated to plant roots are only able to hydrolyze soluble phytate that represents only a small fraction of the total phytate present in the soil. Therefore, a biotechnological approach combining the expression of phytases with increased OA exudation has been suggested as a more effective strategy to increase phytate solubility from phytins (Brinch-Pedersen et al., 2002).

\section{The phosphiteoxidoreductase/phosphite system: a simple solution} for two complex problems

Because $\mathrm{Pi}$ cannot be substituted in plant nutrition, relatively little attention has been given to the use of other chemical forms of $P$ to formulate effective and environmentally friendly fertilizers. After World War II, Phosphite (Phi), a reduced form of P, was proposed as a promising alternative $\mathrm{P}$ fertilizer because of its distinct chemical and biochemical properties compared to $\mathrm{Pi}$, namely, increased solubility, reduced reactivity with soil components, and the inability of most microorganisms to use it as a $P$ source. However, several reports have demonstrated that plants cannot metabolize $\mathrm{Phi}$ and that this reduced $\mathrm{P}$ form decreases plant growth and development. Although Phi formulations are currently sold as $P$ fertilizers, these reports challenge the use of Phi as a direct source of $P$ to support plant growth, and suggests that its known beneficial effects on plant growth are only due to its well-documented properties to control oomycete diseases and its capacity to activate plant defense mechanisms (references in López-Arredondo and Herrera-Estrella, 2012).

Some bacterial species have been described that can oxidize Phi into Pi. The ptxD gene from Pseudomonas stutzeri WM88 encodes a highly Phi-specific oxidoreductase that oxidizes Phi using $\mathrm{NAD}^{+}$as a cofactor, yielding $\mathrm{Pi}$ and NADH as products (Metcalf and Wolfe, 1998). Recently, by means of the ptxD gene from $P$. stutzeri, transgenic Arabidopsis and tobacco plants that metabolize Phi have been generated (López-Arredondo and Herrera-Estrella, 2012). In contrast to wild-type plants, which growth was reduced when fertilized with Phi, PTXD-expressing lines grew equally well when fertilized with Phi than the same lines or the wild-type fertilized with $\mathrm{Pi}$. More importantly, when grown under greenhouse conditions in agricultural soils containing their native microflora, PTXD-expressing lines required $30 \%$ to $50 \%$ less $P$ for an optimal productivity when fertilized with Phi than with Pi (for details, see López-Arredondo and Herrera-Estrella, 2012). These results illustrate that most soil microorganisms are unable to use Phi as a $P$ source and, thus, do not compete with the transgenic plants for its use as nutrient source. Therefore, this genetic modification represents an improvement in the competitiveness of the transgenic plants over the soil microflora, allowing a more effective use of $\mathrm{P}$ resources present in the soil when Phi is applied as fertilizer (Fig. 3). 
Weedy plants also represent a major challenge to agriculture, particularly those that have become resistant to one or more traditional herbicides. Because, in principle, weeds are also unable to metabolize Phi, this reduced $\mathrm{P}$ form could be used as a fertilizer that, in low-Pi containing soils, would prevent or reduce weed growth. Growth competition experiments, in which seeds of PTXD-expressing tobacco had been mixed with seeds from weedy species were sown in low-Pi agricultural soils, revealed that the tobacco plants rapidly outgrew different weedy species when fertilized with Phi (López-Arredondo and Herrera-Estrella, 2012).

Fertilization and weed control based on transgenic plants expressing a phosphite oxidoreductase gene have clear advantages over current $\mathrm{Pi}$ fertilization systems because they exploit the chemical and biological properties of Phi (Fig. 3). In principle, this system is applicable to any cultivated plant species amenable for genetic transformation. Based on its effectiveness in weed control and fertilization under greenhouse conditions, this system could reduce production costs and energy consumption by replacing the independent application of fertilizers and herbicides by a single treatment, thereby also decreasing the cost for additional herbicides.

\section{Engineering iron metabolism to improve plant nutrition and grain fortification}

Iron is one of the most important micronutrients for all living organisms, including humans and plants. This micronutrient is an essential component for a myriad of proteins (e.g. iron-sulfur and heme proteins) involved in a diversity of processes, such as photosynthesis, reactive oxygen species scavenging, transcriptional regulatory networks, mitochondrial electron transport chains, DNA synthesis and repair, sensing, and signaling. Therefore, as a wide- spread utilized element in plants, a tight control of Fe endogenous levels is necessary to satisfy the demand for this nutrient, but also to avoid its toxicity. Excessive levels of Fe have detrimental effects on plant development, mainly due to the reaction of $\mathrm{Fe}$ with hydrogen peroxide, via the well-known Fenton reaction, that produces harmful reactive oxygen species. Disruption of genes encoding iron-reservoir proteins (ferritins), provokes an increase of the oxidant sensitivity in Arabidopsis (Ravet et al., 2009).

\section{Regulation of iron metabolism in plants}

Although $\mathrm{Fe}$ is not required in high amounts by plants, its low solubility in agricultural soils greatly affects crop yield, especially in alkaline soils (Guerinot and Yi, 1994). In nature, free Fe concentration at neutral $\mathrm{pH}$ is in the range of $10^{-17} \mathrm{M}$, which would cause Fe-deficiency symptoms because the required amount for optimal plant growth is between $10^{-9}$ to $10^{-4} \mathrm{M}$ (Guerinot and $\mathrm{Yi}$, 1994). Detailed studies have demonstrated that plants utilize two different pathways that are activated by Fe deficiency to cope with this disadvantageous scenario (Fig. 4A). One of them, known as the "reduction strategy" (Strategy I) is used by most dicotyledonous and monocotyledonous plants, with the exception of graminaceous plants. The reduction strategy depends on the activities of a proton pumping ATPase $\left(\mathrm{H}^{+}\right.$-ATPase $)$that lowers the soil $\mathrm{pH}$ to release $\mathrm{Fe}^{3+}$ from chelating agents and of a root membrane reductase to produce $\mathrm{Fe}^{2+}$ from $\mathrm{Fe}^{3+}$. In several plant species, $\mathrm{H}^{+}$-ATPase-encoding genes have been identified. In Cucumis sativus (cucumber) roots, the plasma membrane $\mathrm{H}^{+}$-ATPase-encoding gene CsHA1, is upregulated in response to Fe-limiting conditions, whereas $\mathrm{CsHA2}$ remains unaltered (Santi et al., 2005). In Arabidopsis roots, two $\mathrm{H}^{+}$-ATPase-encoding genes, $A H A 2$ and $A H A 7$ are also up-regulated under Fe deficiency (Santi and Schmidt, 2009). Analysis of the Fe

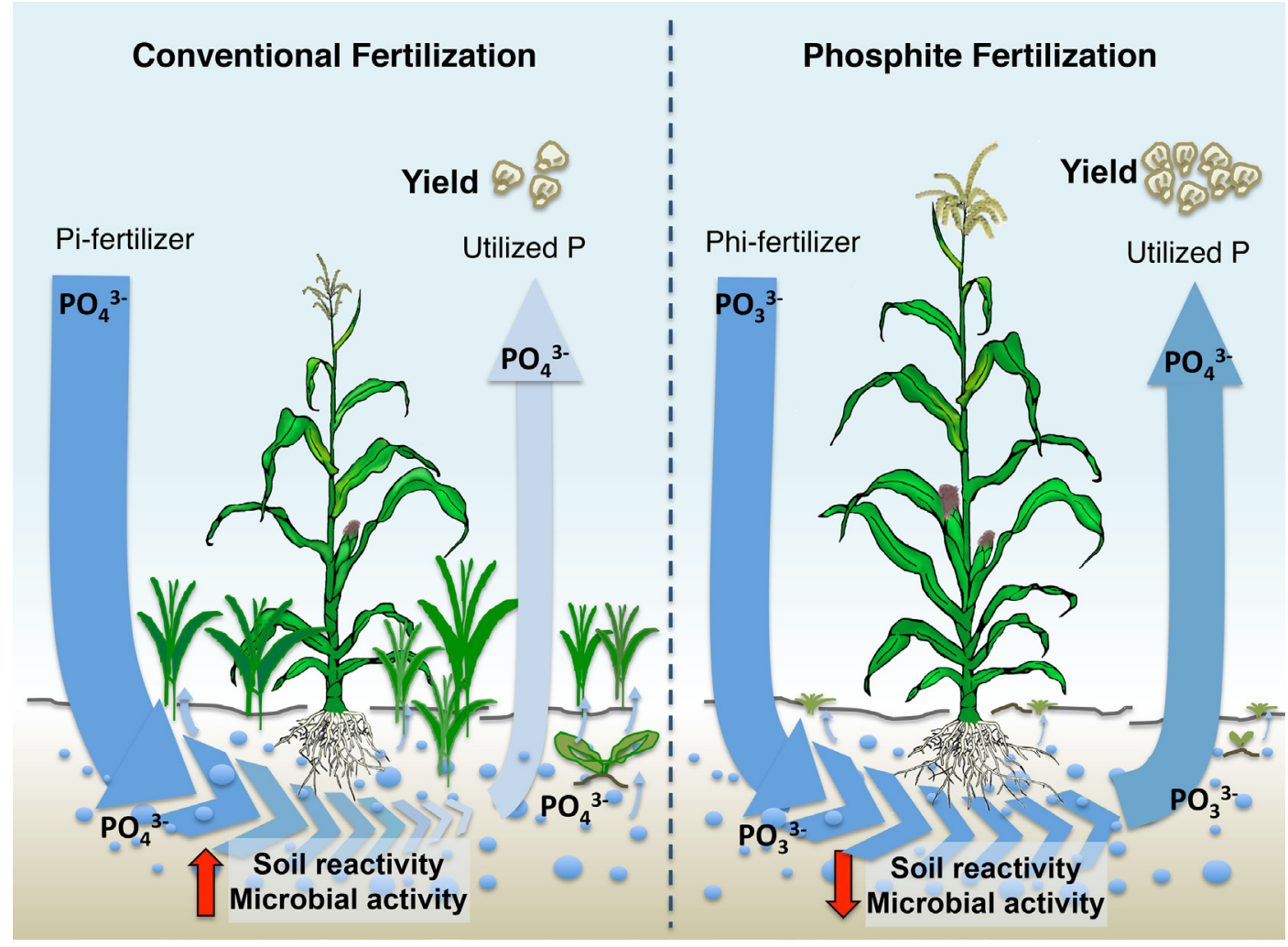

Fig. 3. Phosphite oxydoreductase/phosphite-based fertilization and weed control system. Schematic representation of the performance of a phosphite (Phi) fertilization scheme in comparison to a conventional (phosphate) (Pi) fertilization without use of herbicides. In the conventional fertilization, approximately $70 \%$ to $80 \%$ of the applied Pigets fixed byadsorption or is converted by soil microorganisms into organic compounds not readily available for plant uptake. Additionally, weed growth is promoted by $\mathrm{Pi}$ fertilization. As weeds and most soil microorganisms are unable to use Phi as a phosphorus (P) source, in the Phi fertilization scheme genetically modified plants expressing a phosphite oxidoreductase are more competitive than weeds and soil microorganisms because they can use Phi as sole P source, as illustrated in an increased grain yield. The Phi fertilization system reduces the amount of $P$ fertilizers needed for optimal productivity and also limits the need of herbicides for weed control. 
deprivation responses of aha2 and aha7 mutants revealed that the lack of these $\mathrm{H}^{+}$-ATPases diminishes the capacity of the root to acidify the rhizosphere and to develop root hairs, respectively. These observations suggest that $\mathrm{H}^{+}$-ATPases are important constituents of the Arabidopsis response to Fe deficiency (Santi and Schmidt, 2009). The next step in Fe uptake is the reduction of $\mathrm{Fe}^{3+}$ into the more soluble $\mathrm{Fe}^{2+}$, which is carried out by FERRIC CHELATE REDUCTASE OXIDASE (FRO) (Robinson et al., 1999). Arabidopsis possesses eight $\mathrm{FRO}$-encoding genes, among which FRO2maps and complements the ferric-chelate reductase defective 1 (fdr1) mutant that displays severe chlorosis under Fe-deficient conditions (Robinson et al., 1999). FRO2 is predominantly expressed in root epidermal cells, whereas $F R O 3$, another member of the family, is mainly expressed in the vascular cylinder, hinting at important roles in Fe reabsorption from external Fe uptake and from the apoplast, respectively. In contrast, both FRO5 and FRO6 are expressed in shoots and flowers; whereas FRO7 and FRO8 are shoot specific, suggesting roles in Fe homeostasis in different tissues (Wu et al., 2005).

Once the $\mathrm{Fe}^{2+}$ ion is produced, members of the metal transporter family ZINC-REGULATED TRANSPORTER (ZRT) and IRONREGULATEDTRANSPORTER(IRT)-like PROTEIN (acronym ZIP) carry Fe across the plasma membrane (Eide et al., 1996). In Arabidopsis, the IRON-REGULATEDTRANSPORTER1 (IRT1) gene acts as the major Fe transporter and is expressed in epidermal cells of Fe-starved roots (Vert et al., 2002). irt1 mutants characteristically display chlorosis and severe growth impairment that can be rescued by exogenous Fe (Vert et al., 2002). Interestingly, the homologous IRT2 gene does not complement the irt1 mutant phenotype when overexpressed, suggesting that IRT2 is not involved in Fe uptake (Varotto et al., 2002). Besides Fe, IRT1 also transports zinc (Zn), manganese $(\mathrm{Mn})$, cobalt $(\mathrm{Co})$, and cadmium $(\mathrm{Cd})$ due to its low cation selectivity and its misregulation in the fdr1 and fdr 3 mutants affects the Fe-uptake system (Eide et al., 1996).

Several TFs control the expression of genes involved in the Fe uptake Strategy I. The first TF described was the tomato IRON UPTAKE RESPONSE (FER), a protein with a basic helix-loop-helix (bHLH) domain that, when mutated, affects Fe responses (Ling et al., 2002). In Arabidopsis, a bHLH29 known as FER-LIKE IRON DEFICIENCY INDUCED (FIT), plays a similar role in regulating several low-Fe inducible genes, such as FRO2and IRT1 (Colangelo and Guerinot, 2004). In addition, bHLH38, bHLH39, bHLH100, and bHLH101 were identified as FIT interactors that are induced by Fe deficiency. The transcriptional activity of the heterodimer FIT/ bHLH101 is higher than that of FIT/bHLH100 (Wang et al., 2013a). The double mutants, bh/h39-bh/h100 and bh/h39-bh/h101 and the triple mutant bh/h39-bh/h100-bh/h101 behave as the wild-type in Fe-optimum medium, but under Fe-limiting conditions, they have a significantly reduced plant growth and lower Fe content (Wang et al., 2013a).

Changes in the root system architecture in response to $\mathrm{Fe}$ deficiency have been mainly associated with strategy-I plants, because they depend directly on the root surface area to acidify the rhizosphere and to reduce $\mathrm{Fe}^{3+}$ into $\mathrm{Fe}^{2+}$. In Arabidopsis, the root hair density increases by $42 \%$ and $61 \%$ under $\mathrm{Fe}$ - and $\mathrm{Pi}$-limited conditions, respectively (Müller and Schmidt, 2004). In addition, under Fe deficiency, plants increase the absorptive surface by forming branched root hairs, whereas under low-Pi conditions, the increase in hair density is mainly achieved by the formation of extra hairs (Müller and Schmidt, 2004). Impaired root hair patterning in response to Fe deficiency in mutants affected in genes involved in the first steps of root hair differentiation suggests that the nutritional signals to Fe deficiency are perceived at early stages of epidermal cell development. For instance, root hair branching in Fe-deficient roots is lost in transparent testa glabra1 (ttg1), glabra2 ( $g / 2)$, caprice $(c p c)$, ectopic root hair1 (erh1), and erh3 mutants (Müller and Schmidt, 2004). Recently, two ubiquitin-conjugating enzymes, UBC13A and UBC13B, have been identified that specifically regulate root hair branching in response to $\mathrm{Fe}$ availability in Arabidopsis (Li and Schmidt, 2010). It would be very interesting to

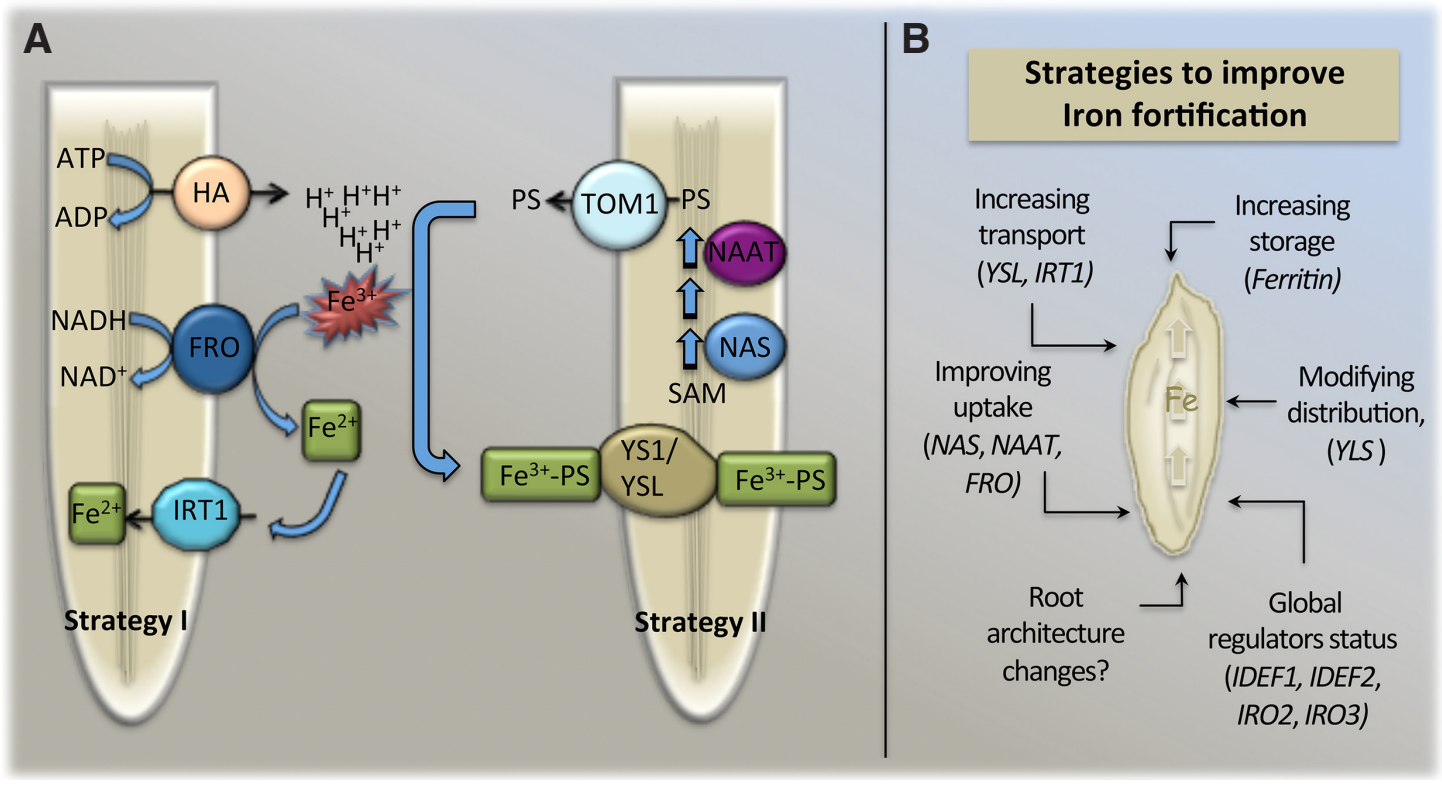

Fig. 4. Plant strategies of iron uptake and biotechnological efforts to improve iron content in seeds. (A) Schematic representation of the two main iron uptake systems in plants. (B) Biotechnological efforts that have resulted in increased iron content in rice. 
test whether controlling root hair length and density could positively affect plant growth in crop plants as reported for Arabidopsis plants grown under low-Pi conditions.

The second strategy for Fe uptake, known as "chelation strategy" (Strategy II), is used by major cereal crops, such as maize, wheat, barley, Avena sativa (oat), and rice (Fig. 4). This strategy involves the secretion of the mugineic acid (MA) family phytosiderophores from the root system into the rhizosphere. These phytosiderophores chelate $\mathrm{Fe}^{3+}$-containing compounds, and the complexes are taken up by a specific transport system in the root plasma membrane (Guerinot and Yi, 1994). MA biosynthesis involves the condensation of three $S$-adenosyl-L-methionine (SAM) molecules, by the nicotianamine synthase (NAS), to form nicotianamine (NA) (Bashir et al., 2006). Thereafter, a nicotianamine aminotransferase (NAAT) and a 2-deoxymugineic acid (DMA) synthase (DMAS) catalyze the following reactions to produce DMA, the precursor of all MAs (Bashir et al., 2006). MAs are secreted into the rhizosphere via the TRANSPORTER OF MUGINEIC ACID FAMILY PHYTOSIDEROPHORES1 (TOM1), which is highly expressed in the roots of rice and barley plants in response to Fe-deficiency (Nozoye et al., 2011).

The $\mathrm{Fe}^{3+}$-phytosiderophorePS complex is taken up into the root by the YELLOW STRIPE1 (YS1) and YS1-like (YSL) transporters (Curie et al., 2001; Inoue et al., 2009). In rice, there are18 YSL members, of which OsYSL15 is predominantly active in the transport of $\mathrm{Fe}^{3+}$-DMA complexes from the rhizosphere (Inoue et al., 2009). In addition, some YS1 transporters have been identified in barley and maize (HvYS1 and ZmYS1, respectively) (Murata et al., 2006).

A set of TFs has been found to control low-Fe responses in plant species that use the chelation strategy. The IRON DEFICIENCYRESPONSIVEELEMENT-BINDINGFACTORS1 (IDEF1) and IDEF2 were identified in rice because of its capacity to bind two cis-acting elements (IDE1 and IDE2) required for the transcriptional activation of Fe-responsive genes (Kobayashi et al., 2007; Ogo et al., 2007). These motifs are present in the promoter of the barley gene IRONDEFICIENCY SPECIFIC CLONE2(IDS2), which is implicated in MA biosynthesis, and are widely distributed in the promoters of other low-Fe-regulated genes. Recently, IDEF1 has been found to bind $\mathrm{Fe}$ and $\mathrm{Zn}$ directly through histidine-asparagine and proline-rich regions, suggesting that this TF could be involved in Fe sensing (Kobayashi et al., 2012). In rice, IDEF1 targets IRON-RELATED TRANSCRIPTION FACTOR2 (OsIRO2), a bHLH TF that acts as positive regulator of $59 \mathrm{Fe}$ deficiency-inducible root-specific genes (Ogo etal., 2007). Although no phenotypic differences between wildtype and OsIRO2-overexpressing plants had been observed under Fe-sufficient conditions, these transgenic plants perform better than the wild-type under Fe-limited conditions, without alterations in total Fe content, but with increased secretion of MAs (Ogo et al., 2007).

OsIRO3 is a bHLH-negative regulator of $\mathrm{Fe}$ responses in rice that is strongly and specifically induced by Fe deficiency (Zheng et al., 2010). OsIRO3 overexpression results in hypersensitivity to Fe deficiency, decreased shoot Fe content, and reduced transcriptional responses to Fe limitation. These observations hint at an important role for OsIRO3 in Fe homeostasis (Zheng et al., 2010). Therefore, OsIRO3 silencing could be a potential strategy to enhance Fe deprivation tolerance.

Interestingly, orthologs of some components of Strategy I have been identified in rice, one of the most important Strategy II crop plants. In rice, two IRT genes, OsRT1 and OsRT2, are mainly expressed in roots and induced by Fe deficiency (Bughio et al., 2002;
Ishimaru et al., 2006). The presence of this kind of $\mathrm{Fe}^{2+}$ transporters in rice is considered an adaptation to the submerged and anaerobic growing conditions. Rice also has two FRO1-like genes, OsFRO1 and OsFRO2, but the gene products have no reductase activity (Ishimaru et al., 2006). Expression of IRT genes in other important crops with active Strategy II could be an interesting approach to study their contribution in Fe uptake.

\section{Genetic engineering approaches for improving iron content in plants}

The issue of improving Fe uptake and assimilation in plants has received great attention not only to produce healthy plants in the field, but also to increase Fe content and bioavailability for human nutrition. According to some estimations, approximately $30 \%$ of the world's population suffers from some degree of Fe deficiency, with a higher prevalence in developing countries. Therefore, improving Fe content in cereals that support human nutrition in low-income countries, such as rice, maize, and wheat, is urgent.

Several strategies have been attempted by different research groups, including better crop management, traditional breeding, and genetic engineering. Efforts to increase Fe uptake by genetic modifications has focused on key regulatory elements of the Fe uptake pathways described above (Fig. 4B). Nevertheless, it is important to note that although some promising results have been obtained, those that expressed Strategy I genes in plants that naturally use Strategy II, have failed to improve Fe assimilation, demonstrating the high complexity of Fe uptake and homeostasis in plants.

\section{Candidate genes involved in transport and reduction of iron}

In Strategy I plants, overexpression of IRT genes resulted in plants that accumulate more divalent metals in both sufficient and limited Feregimens. For instance, Arabidopsis IRT1-overexpressing plants accumulate up to 3-fold higher Fe leaf content in Fe-sufficient media than control plants (Barberon et al., 2011). However, overexpression of IRT1 has also detrimental effects on plant growth due to the oxidative stress caused by the increased uptake of other divalent metals such as Zn, Co, and Mn (Barberon etal., 2011). One possibility to solve this problem is to make this transporter more specific for Fe uptake. Two amino acid substitutions have proven to be effective in this regard: the replacement of the Glu residue at position 103 by an alanine (Ala) eliminates Zn transport activity, and the replacement of Asp residues residues at positions 100 and 136 by Ala eliminate $\mathrm{Zn}$ and $\mathrm{Mn}$ transport activities, respectively (Rogers et al., 2000). However, substitution of the Asp residue by Ala also eliminates Fe transport.

The rate-limiting step in Fe uptake through Strategy I is $\mathrm{Fe}^{3+}$ reduction (Connolly et al., 2003). Therefore, overexpression of FRO2 enhances the capacity of Arabidopsis to grow under Felimited conditions thanks to an increased FRO activity (Connolly et al., 2003). However in FRO2-overexpressing lines grown under Fe-sufficient conditions, FRO activity is not enhanced, hinting at a posttranscriptional component in FRO2 regulation (Connolly et al., 2003). Interestingly, a yeast FRO mutant has been generated with improved activity at alkaline pH (Ishimaru et al., 2007). Transgenic rice plants expressing this yeast mutant $F R O$ gene under the promoter of the $\mathrm{Fe}^{2+}$ transporter OsIRT1 displayed an almost 8-fold increase in grain yield in calcareous soil, due to a 2.2-fold and 1.8-fold increment in ferric chelate reductase activity at pH 5.5 and 8.0, respectively (Ishimaru et al., 2007). Despite this 
important step, the Fe content in rice grains remained unaltered indicating that, in addition to enhancing Fe uptake, improving $\mathrm{Fe}$ translocation and distribution is also necessary.

\section{Genetic modifications involving transcription factors}

Controlling the expression of master regulators that orchestrate many responses to low-Fe could be an effective way to produce plants with enhanced Fe-uptake capacity. Yuan and co-workers (2008) overexpressed either the bHLH38 or bHLH39 FIT interactors, in transgenic plants that overexpress FIT(Yuan etal., 2008). These plants constitutively expressed several low-Fe-inducible genes and had a 2- to 5-fold higher Fe-content in shoots, independent of the Fe supply (Yuan et al., 2008). Additionally, co-expression of FIT and its bHLH101 interactor in Arabidopsis conferred a Fe deficiency-tolerant phenotype and a significantly enhanced $\mathrm{Fe}$ accumulation in shoots both under Fe-deficient and Fe-sufficient conditions (Wang et al., 2013a).

Overexpression of IDEF1, under the control of the constitutive $35 S$ promoter or the IDS2 promoter, produced plants that were able to grow better under Fe-limited conditions as revealed by a slower decline in leaf chlorophyll in transgenic lines than in wildtype plants. Analysis of the Fe content in transgenic and wild-type plants grown after Fe-deficient treatments showed that both lines had similar Fe concentrations, suggesting that the improved performance of IDEF1-overexpressing lines was due to a better Fe utilization within the plant instead of an enhanced Fe-uptake from the rhizosphere (Kobayashi et al., 2007). Likewise, IDEF2 is a TF involved in the regulation of several Fe-responsive genes, including the $\mathrm{Fe}^{3+}$-nicotianamine transporter gene OsYSL2, by direct binding to its promoter region (Ogo et al., 2007). Down-regulation of IDEF2 by RNAi caused Fe overaccumulation in shoots and roots of plants growing under Fe-sufficient conditions and in roots under low-Fe conditions, indicating that IDEF2 participates in Fe uptake or translocation (Ogo et al., 2007). Overexpression of these TFs in economically important plants is the next step to demonstrate the feasibility of these types of strategies to improve tolerance to Fe deficiency under field conditions.

Genetic modifications involving mugineic acid biosynthesis and transport

Increasing the transport of Fe-MAcomplexes in developing seeds also produces fortified grains in Strategy II plants. For instance, overexpression of the OSYLS2gene under control of the SUCROSE TRANSPORTER 1 (SUT1) promoter causes a 4.4-fold increase in Fe content in rice grains (Ishimaru et al., 2010). Moreover, because plants that naturally produce more MAs, such as barley, are more tolerant to low-Fe environments, a promising strategy to improve Fe assimilation in the most important cereals (e.g. maize, rice, wheat) might be to increase phytosidorophore biosynthesis and/or secretion (Takahashi et al., 2001), as confirmed through the expression of two barley MA-biosynthetic genes (NAAT-A and NAAT-B) in rice. In alkaline soils with low-Fe availability, transgenic rice lines expressing $N A A T-A$ and $N A A T-B$ had higher DMA production and perform better under Fe-deficient conditions, producing 4.1-fold higher grain yields than untransformed controls plants (Takahashi et al., 2001). Overexpression of nicotianamine-encoding genes, such as OsNAS3 in rice, also resulted in rice plants with increased Fe content. These plants accumulated 1.7- and 1.6-fold more Fe in shoots and roots, respectively, when grown in Fe-sufficient media, whereas under Fe deficiency, they accumulated 2.2- and 2.0-fold more $\mathrm{Fe}$ in shoots and roots, respectively (Lee et al., 2009). Moreover, grains of OsNAS3-overexpressing plants contained 2.9-fold more Fe than control plants and, when tested in anemic mice, were able to revert to the low hematocrit and hemoglobin levels, also suggesting an increase in Fe bioavailability (Lee et al., 2009).

Overexpression of two other nicotianamine-encoding genes, OsNA1 and OsNA2 also produces an increase in Fe content in rice grains. Fe content in lines overexpressing OsNA1 and OsNA2-overexpressing lines was up to 2.4-fold and 3.5-fold higher, respectively, than that of wild-type plants (Johnson et al., 2011). Interestingly, the endosperm of one OsNA2-overexpressing line contained $19 \mu \mathrm{g} / \mathrm{g} \mathrm{Fe}$, which could supply the amount of Fe (14.5 $\mu \mathrm{g} / \mathrm{g}$ ) that a rice-based diet should contain (Johnson et al., 2011).

\section{Genetic modifications to improve the content of ferritins as iron} reservoir proteins

The most promising approach to increase Fe content in seeds may be the overproduction of ferritins. These proteins play essential roles in controlling oxidative stress and Fe homeostasis and are the main Fe-storage proteins in animals and plants. However, ferritins are not the main Fe reservoirs in seeds or leaves (Ravet et al., 2009). Rice grains of plants overexpressing a soybean ferritin under control of the rice glutelin promoter GluB-1 accumulate up to 3-fold more Fe than wild-type seed (Goto et al., 1999). Similarly, a 13-fold increase in ferritin content in rice grains could be achieved with a stronger promoter (Qu et al., 2005), but only a 30\% higher Fe concentration than control plants. These results suggest that Fe content in seeds could be limited by Fe uptake and transport in ferritin-overexpressing lines. More than 6-fold increased Fe content in rice endosperm was obtained by concomitantly expressing NAS and ferritin genes, confirming a synergistic effect on Fe uptake and storage (Wirth et al., 2009).

An interesting strategy to increase Fe bioavailability in grains is the overexpression of phytase-encoding genes, because phytate in seeds contains from $60 \%$ to $90 \%$ of the total $\mathrm{Pi}$ (Loewus, 2002). Moreover, due to its high affinity to several minerals, including Fe, $\mathrm{Zn}$, and $\mathrm{Ca}$, phytate also affects their bioavailability. Lucca and co-workers expressed a thermostable phytase from Aspergillus fumigatus in the rice endosperm and, despite that the transgenic rice grains showed enhanced phytase activity, it was destroyed after cooking, maintaining only $8 \%$ of the activity prior treatment (Lucca et al., 2001). More recently, the expression of two different phytase genes ( $p h y A$ and appA, from Aspergillus niger and $E$. coli, respectively) in canola produced transgenic seeds with lower amounts of phytic acid than the wild-type. Although the authors did not perform Fe analysis, it could be expected that Fe bioavailability could have also been improved (Wang et al., 2013b), representing a better solution for the nutrient availability of $\mathrm{P}$ and $\mathrm{Fe}$, at least for monogastric animals.

\section{Conclusions}

The requirement of crop varieties with high nutrient use efficiency has been discussed historically. Increasing food production and improving food quality have always been needed worldwide. However, the increasing fertilizer consumption rates focused on human and animal food production and the growing population has alerted research groups to develop urgently more efficient 
agricultural schemes to use natural resources more rationally. In the past, the limited knowledge on plant metabolism affected the development of these improved varieties, but the tools are now available to genetically modify many plant species. Systems biology has accelerated the discovery of regulatory elements in several pathways with the potential to improve plant performance in the field.

As discussed above, there are numerous attempts to improve nutrient use in plants through the manipulation of enzymes and proteins directly involved in uptake and assimilation of a specific nutrient, but only a few have produced results sufficiently promising for their commercial application. As the accumulation or activity of these proteins can be modulated by various processes (translational and posttranslational), it is necessary to understand these mechanisms to ensure successful trait modification. To achieve this aim, available information on the different nutrients must be integrated with the growing experimental data under various nutritional regimens for several plant species. Such an integration would help to identify critical components that could allow the effective alteration of nutrient use efficiency in important crops.

It is important to note that to improve assimilation efficiencies for all nutrients, external nutrient acquisition must be taken into account. The root system is central for water and nutrient uptake; therefore, understanding the mechanism that control root system architecture as well as its interaction with the rhizosphere components that influence nutrient availability, will help to improve nutrient use efficiency of any crop plant. Hence, phenotype analysis of plants must be carried out under field conditions. In addition, the reincorporation of traits conferring tolerance to nutrient deficiency, naturally present in wild or traditional cultivars, could be used to enhance nutrient uptake and applied in modern crop varieties. It is also important to consider a more extensive study of positive side effects of overexpressing specific regulatory elements on pathogen and drought resistance. Indeed, if current advances in plant nutrient research and technologies developed with the use of bacterial genes are implemented in crops and if the application of fertilizers is effectively reduced, a more sustainable and ecologically benign second Green Revolution will emerge.

\section{Acknowledgements}

This work was supported in part by the Howard Hughes Medical Institute (grant no. 55005946) and Consejo Nacional de Ciencia y Tecnología (CONACyT; México) (to L.H.-E.). D.L.L.A. is indebted to CONACyT (México) for a PhD fellowship (No. 203571).

\section{References}

ALATORRE-COBOS F, LÓPEZ-ARREDONDO D, HERRERA-ESTRELLA L (2009). Genetic determinants of phosphate use efficiency in crops. In Genes for Plant Abiotic Stress (Eds MA Jenks and AJ Wood). Wiley-Blackwell, Oxford, pp. 143-165.

AMEZIANE R, BERNHARD K, LIGHTFOOT D (2000). Expression of the bacterial gdhA gene encoding a NADPH glutamate dehydrogenase in tobacco affects plant growth and development. Plant Soil 221: 47-57.

ASHIKARI M, SAKAKIBARA H, LIN S, YAMAMOTO T, TAKAHASHI T, NISHIMURA A, ANGELES ER, QIAN Q, KITANO H, MATSUOKA M (2005) Cytokinin oxidase regulates rice grain production. Science 309: 741-745.

BARBERON M, ZELAZNY E, ROBERT S, CONÉJÉRO G, CURIE C, FRIML J, VERT G (2011) Monoubiquitin-dependent endocytosis of the IRON-REGULATED TRANSPORTER 1 (IRT1) transporter controls iron uptake in plants. Proc Natl Acad Sci USA 108: 12985-12986 (E450-E458).

BASHIR K, INOUE H, NAGASAKA S, TAKAHASHI M, NAKANISHI H, MORI S, NISHIZAWA NK (2006). Cloning and characterization of deoxymugineic acid synthase genes from graminaceous plants. J Biol Chem 281: 32395-32402.

BI Y-M, KANT S, CLARK J, GIDDA S, MING F, XU J, ROCHON A, SHELP BJ, HAO L, ZHAO R, MULLEN RT, ZHU T, ROTHSTEIN SJ (2009). Increased nitrogenuse efficiency in transgenic rice plants over-expressing a nitrogen-responsive early nodulin gene identified from rice expression profiling. Plant Cell Environ 32: 1749-1760.

BOUGUYON E, GOJONA, NACRY P (2012). Nitrate sensing and signaling in plants. Semin. Cell Dev Biol 23: 648-654.

BRINCH-PEDERSENH, SØRENSEN LD, HOLM PB (2002). Engineering crop plants: getting a handle on phosphate. Trends Plant Sci 7: 118-125.

BUGHIO N, YAMAGUCHI H, NISHIZAWA NK, NAKANISHI H, MORI S (2002). Cloning an iron-regulated metal transporter from rice. J Exp Bot 53: 1677-1682.

CAKMAK I (2002). Plant nutrition research: priorities to meet human needs for food in sustainable ways. Plant Soil 247: 3-24.

CASTAINGS L, CAMARGO A, POCHOLLE D, GAUSON V, TEXIER Y, BOUTETMERCEY S, TACONNAT L, RENOU J-P, DANIEL-VEDELE F, FERNANDEZ E, MEYER C, KRAPPA(2009). The nodule inception-like protein 7 modulates nitrate sensing and metabolism in Arabidopsis. Plant J 57: 426-435.

COLANGELO EP, GUERINOT ML (2004). The essential basic helix-loop-helix protein FIT1 is required for the iron deficiency response. Plant Cell 16: 3400-3412.

CONNOLLY EL, CAMPBELL NH, GROTZN, PRICHARD CL, GUERINOT ML (2003). Overexpression of the $\mathrm{FRO} 2$ ferric chelate reductase confers tolerance to growth on low iron and uncovers posttranscriptional control. Plant Physiol133: 1102-1110.

CURIE C, PANAVIENE Z, LOULERGUE C, DELLAPORTA SL, BRIAT J-F, WALKER EL (2001) Maize yellow stripe1 encodes a membrane protein directly involved in Fe(III) uptake. Nature 409: 346-349.

DAI X, WANG Y, YANG A, ZHANG W-H (2012). OsMYB2P-1, an R2R3 MYB transcription factor, is involved in the regulation of phosphate-starvation responses and root architecture in rice. Plant Physiol 159: 169-183.

DE LA FUENTE JM, RAMÍREZ-RODRÍGUEZ V, CABRERA-PONCE JL, HERRERAESTRELLA L (1997). Aluminum tolerance in transgenic plants by alteration of citrate synthesis. Science 276: 1566-1568.

DJENNANES, CHAUVIN J-E, QUILLERÉ I, MEYER C, CHUPEAUY (2002). Introduction and expression of a deregulated tobacco nitrate reductase gene in potato lead to highly reduced nitrate levels in transgenic tubers. Transgenic Res 11: 175-184.

EIDE D, BRODERIUS M, FETT J, GUERINOT ML (1996) A novel iron-regulated metal transporter from plants identified by functional expression in yeast. Proc Natl Acad Sci USA 93: 5624-5628.

FEI H, CHAILLOU S, HIREL B, POLOWICK P, MAHON JD, VESSEY JK (2006). Effects of the overexpression of a soybean cytosolic glutamine synthetase gene (GS15) linked to organ-specific promoters on growth andánitrogen accumulation of pea plants supplied with ammonium. Plant Physiol Biochem 44: 543-550.

GAN Y, BERNREITERA, FILLEUR S, ABRAM B, FORDE BG (2012) Overexpressing the ANR1 MADS-box gene in transgenic plants provides new insights into its role in the nitrate regulation of root development. Plant Cell Physiol 53: 1003-1016.

GEORGE TS, SIMPSON RJ, HADOBAS PA, RICHARDSON AE (2005). Expression of a fungal phytase gene in Nicotiana tabacum improves phosphorus nutrition of plants grown in amended soils. Plant Biotechnol J 3: 129-140.

GIANNINO D, NICOLODI C, TESTONE G, FRUGIS G, PACE E, SANTAMARIA P, GUARDASOLE M, MARIOTTI D (2008). The overexpression of asparagine synthetase A from $E$. coli affects the nitrogen status in leaves of lettuce (Lactuca sativa L.) and enhances vegetative growth. Euphytica 162: 11-22.

GIFFORD ML, DEAN A, GUTIERREZ RA, CORUZZI GM, BIRNBAUM KD (2008) Cell-specific nitrogen responses mediate developmental plasticity. Proc Natl Acad Sci USA 105: 803-808.

GILBERT N (2009). The disappearing nutrient. Nature 461: 716-718 [Erratum Nature 461: 1041; Nature 462: 404].

GOJONA, KROUKG, PERRINE-WALKER F, LAUGIERE (2011) Nitrate transceptor(s) in plants. J Exp Bot 62: 2299-2308.

GOOD AG, JOHNSON SJ, DE PAUW M, CARROLL RT, SAVIDOV N, VIDMAR J, LU Z, TAYLOR G, STROEHER V (2007). Engineering nitrogen use efficiency with alanine aminotransferase. Can J Bot 85: 252-262.

GOOD AG, SHRAWAT AK, MUENCH DG (2004). Can less yield more? Is reducing nutrient input into the environment compatible with maintaining crop production? Trends Plant Sci 9: 597-605. 
GOTOF, YOSHIHARAT, SHIGEMOTON, TOKIS, TAKAIWAF (1999). Iron fortification of rice seed by the soybean ferritin gene. Nat Biotechnol 17: 282-286.

GUERINOT ML, YI Y (1994). Iron: nutritious, noxious, and not readily available. Plant Physiol 104: 815-820.

HWANG IS, AN SH, HWANG BK (2011). Pepper asparagine synthetase 1 (CaAS1) is required for plant nitrogen assimilation and defense responses to microbial pathogens. Plant J 67: 749-762.

INOUE H, KOBAYASHI T, NOZOYE T, TAKAHASHI M, KAKEI Y, SUZUKI K, NAKAZONO M, NAKANISHI H, MORI S, NISHIZAWA NK (2009). Rice OSYSL15 is an iron-regulated iron(III)-deoxymugineic acid transporter expressed in the roots and is essential for iron uptake in early growth of the seedlings. $J$ Biol Chem 284: 3470-3479.

ISHIMARU Y, KIM S, TSUKAMOTO T, OKI H, KOBAYASHI T, WATANABE S, MATSUHASHI S, TAKAHASHI M, NAKANISHI H, MORI S, NISHIZAWA NK (2007). Mutational reconstructed ferric chelate reductase confers enhanced tolerance in rice to iron deficiency in calcareous soil. Proc Natl Acad Sci USA 104: 7373-7378.

ISHIMARU Y, MASUDA H, BASHIR K, INOUE H, TSUKAMOTO T, TAKAHASHI M, NAKANISHI H, AOKI N, HIROSE T, OHSUGI R, NISHIZAWA NK (2010). Rice metal-nicotianamine transporter, OsYSL2, is required for the long-distance transport of iron and manganese. Plant J 62: 379-390.

ISHIMARUY, SUZUKI M, TSUKAMOTOT, SUZUKIK, NAKAZONO M, KOBAYASHIT, WADA Y, WATANABE S, MATSUHASHI S, TAKAHASHI M, NAKANISHI H, MOR $\mathrm{S}$, NISHIZAWA NK (2006). Rice plants take up iron as an $\mathrm{Fe}^{3+}$-phytosiderophore and as $\mathrm{Fe}^{2+}$. Plant $J$ 45: 335-346.

JIANG L, LIU Y, SUN H, HAN Y, LI J, LI C, GUO W, MENG H, LI S, FAN Y, ZHANG C (2013). The mitochondrial folylpolyglutamate synthetase gene is required for nitrogen utilization during early seedling development in Arabidopsis. Plant Physiol 161: 971-989.

JOHNSON AAT, KYRIACOU B, CALLAHAN DL, CARRUTHERS L, STANGOULIS J, LOMBI E, TESTER M (2011). Constitutive overexpression of the OsNAS gene family reveals single-gene strategies for effective iron- and zinc-biofortification of rice endosperm. PLOS ONE 6: e24476.

KIBAT, FERIA-BOURRELLIERA-B, LAFOUGE F, LEZHNEVAL, BOUTET-MERCEY S, ORSEL M, BRÉHAUT V, MILLER A, DANIEL-VEDELE F, SAKAKIBARA H, KRAPP A (2012). The Arabidopsis nitrate transporter NRT2.4 plays a double role in roots and shoots of nitrogen-starved plants. Plant Cell 24: 245-258.

KIBA T, KUDO T, KOJIMA M, SAKAKIBARA H (2011). Hormonal control of nitrogen acquisition: roles of auxin, abscisic acid, and cytokinin. J Exp Bot 62: 1399-1409.

KOBAYASHI T, ITAI RN, AUNG MS, SENOURA T, NAKANISHI H, NISHIZAWA NK (2012). The rice transcription factor IDEF1 directly binds to iron and other divalent metals for sensing cellular iron status. Plant $J 69:$ 81-91.

KOBAYASHIT, OGOY, ITAI RN, NAKANISHI H, TAKAHASHI M, MORIS, NISHIZAWA NK (2007). The transcription factor IDEF1 regulates the response to and tolerance of iron deficiency in plants. Proc Natl Acad Sci USA 104: 19150-19155.

KROUK G, CRAWFORD NM, CORUZZI GM, TSAY Y-F (2010). Nitrate signaling: adaptation to fluctuating environments. Curr Opin Plant Biol 13: 266-273.

KUMAGAI E, ARAKI T, HAMAOKA N, UENO O (2011). Ammonia emission from rice leaves in relation to photorespiration and genotypic differences in glutamine synthetase activity. Ann Bot 108: 1381-1386.

KURAI T, WAKAYAMA M, ABIKO T, YANAGISAWA S, AOKI N, OHSUGI R (2011). Introduction of the $Z m D$ of1 gene into rice enhances carbon and nitrogen assimilation under low-nitrogen conditions. Plant Biotechnol J 9: 826-837.

LAM H-M, WONG P, CHAN H-K, YAM K-M, CHEN L, CHOW C-M, CORUZZI GM (2003). Overexpression of the $A S N 1$ gene enhances nitrogen status in seeds of Arabidopsis. Plant Physiol 132: 926-935.

LAUGIER E, BOUGUYON E, MAURIÈS A, TILLARD P, GOJON A, LEJAY L (2012). Regulation of high-affinity nitrate uptake in roots of Arabidopsis depends predominantly on posttranscriptional control of the NRT2.1/NAR2.1 transport system. Plant Physiol 158: 1067-1078.

LEE S, JEON US, LEE SJ, KIM Y-K, PERSSON DP, HUSTED S, SCHJØRRING JK, KAKEI Y, MASUDA H, NISHIZAWA NK, AN G (2009). Iron fortification of rice seeds through activation of the nicotianamine synthase gene. Proc Natl Acad Sci USA 106: 22014-22019.

LI W, SCHMIDT W (2010). A lysine-63-linked ubiquitin chain-forming conjugase, UBC13, promotes the developmental responses to iron deficiency in Arabidopsis roots. Plant J 62: 330-343.
LING H-Q, BAUER P, BERECZKY Z, KELLER B, GANAL M (2002) The tomato fer gene encoding a bHLH protein controls iron-uptake responses in roots. Proc Natl Acad Sci USA 99: 13938-13943.

LOEWUS FA (2002). Biosynthesis of phytate in food grains and seeds. In Food Phytates (Eds NR Reddy and SK Sathe). CRC Press, Boca Raton, FLA, pp. 53-61.

LÓPEZ-ARREDONDO DL, HERRERA-ESTRELLAL(2012). Engineering phosphorus metabolism in plants to produce a dual fertilization and weed control system. Nat Biotechnol 30: 889-893.

LÓPEZ-BUCIO J, MARTíNEZ DE LA VEGA O, GUEVARA-GARCÍA A, HERRERAESTRELLA L (2000). Enhanced phosphorus uptake in transgenic tobacco plants that overproduce citrate. Nat Biotechnol 18: 450-453.

LU YE, LUO F, YANG M, LI XH, LIAN XM (2011). Suppression of glutamate synthase genes significantly affects carbon and nitrogen metabolism in rice (Oryza sativa L.). Sci China Life Sci 54: 651-663.

LUCCA P, HURRELL R, POTRYKUS I (2001). Genetic engineering approaches to improve the bioavailability and the level of iron in rice grains. Theor Appl Genet 102: 392-397.

MAX-F, WRIGHT E, GE Y, BELL J, XI Y, BOUTON JH, WANG Z-Y (2009). Improving phosphorus acquisition of white clover (Trifolium repens $\mathrm{L}$.) by transgenic expression of plant-derived phytase and acid phosphatase genes. Plant Sci 176: 479-488.

MCALLISTER CH, BEATTYPH, GOOD AG (2012). Engineering nitrogen use efficient crop plants: the current status. Plant Biotechnol J 10: 1011-1025.

METCALFWW, WOLFE RS (1998). Molecular genetic analysis of phosphite and hypophosphite oxidation by Pseudomonas stutzeriWM88. J Bacteriol 180:5547-5558.

MIGGE A, CARRAYOL E, HIREL B, BECKER TW (2000). Leaf-specific overexpression of plastidic glutamine synthetase stimulates the growth of transgenic tobacco seedlings. Planta 210: 252-260.

MILLER JM, FAN X, SHEN Q, SMITH SJ (2007). Amino acids and nitrate as signals for the regulation of nitrogen acquisition. $J$ Exp Bot 59: 111-119.

MITSUKAWA N, OKUMURA S, SHIRANO Y, SATO S, KATO T, HARASHIMA S SHIBATA D (1997). Overexpression of an Arabidopsis thaliana high-affinity phosphate transporter gene in tobacco cultured cells enhances cell growth under phosphate-limited conditions. Proc Natl Acad Sci USA 94: 7098-7102.

MIURA K, LEE J, GONG Q, MA S, JIN JB, YOO CY, MIURA T, SATO A, BOHNERT HJ, HASEGAWA PM (2011). SIZ1 regulation of phosphate starvation-induced root architecture remodeling involves the control of auxin accumulation. Plant Physiol 155: 1000-1012.

MÜLLER M, SCHMIDT W (2004) Environmentally induced plasticity of root hair development in Arabidopsis. Plant Physiol 134: 409-419.

MURATA Y, MA JF, YAMAJI N, UENO D, NOMOTO K, IWASHITA T (2006). A specific transporter for iron(III)-phytosiderophore in barley roots. Plant $J$ 46: 563-572.

NILSSONL, MÜLLERR, NIELSENTM (2007). Increased expression of the MYB-related transcription factor, PHR1, leads to enhanced phosphate uptake in Arabidopsis thaliana. Plant Cell Environ 30: 1499-1512.

NOZOYET, NAGASAKAS, KOBAYASHIT, TAKAHASHI M, SATOY, SATOY, UOZUMI N, NAKANISHIH, NISHIZAWANK (2011). Phytosiderophore efflux transporters are crucial for iron acquisition in graminaceous plants. J Biol Chem 286: 5446-5454.

OGOY, ITAI RN, NAKANISHIH, KOBAYASHIT, TAKAHASHI M, MORIS, NISHIZAWA NK (2007). The rice bHLH protein OsIRO2 is an essential regulator of the genes involved in Fe uptake under Fe-deficient conditions. Plant J 51: 366-377.

QU LQ, YOSHIHARA T, OOYAMAA, GOTO F, TAKAIWA F (2005) Iron accumulation does not parallel the high expression level of ferritin in transgenic rice seeds. Planta 222: 225-233.

QUILLERÉ I, DUFOSSÉ C, ROUX Y, FOYER CH, CABOCHE M, MOROT-GAUDRY J-F (1994). The effects of deregulation of NR gene expression on growth and nitrogen metabolism of Nicotiana plumbaginifolia plants. J Exp Bot45: 1205-1211.

RAE AL, JARMEY JM, MUDGE SR, SMITH FW (2004). Over-expression of a highaffinity phosphate transporter in transgenic barley plants does not enhance phosphate uptake rates. Funct Plant Biol 31: 141-148.

RAVET K, TOURAINE B, BOUCHEREZ J, BRIAT J-F, GAYMARD F, CELLIER F (2009) Ferritins control interaction between iron homeostasis and oxidative stress in Arabidopsis. Plant J 57: 400-412.

REMANS T, NACRY P, PERVENT M, GIRIN T, TILLARD P, LEPETIT M, GOJON A (2006b) A central role for the nitrate transporter NRT2.1 in the integrated morphological and physiological responses of the root system to nitrogen limitation 
in Arabidopsis. Plant Physiol 140: 909-921.

REMANS T, NACRY P, PERVENT M, FILLEUR S, DIATLOFF E, MOUNIER E, TILLARD P, FORDE BG, GOJON A (2006a). The Arabidopsis NRT1.1 transporter participates in the signaling pathway triggering root colonization of nitrate-rich patches. Proc Natl Acad Sci USA 103: 19206-19211.

REMY E, CABRITO TR, BATISTA RA, TEIXEIRA MC, SÁ-CORREIA I, DUQUE P (2012). The Pht1;9 and Pht1;8 transporters mediate inorganic phosphate acquisition by the Arabidopsis thaliana root during phosphorus starvation. New Phytol 195: 356-371.

REN F, GUO Q-Q, CHANG L-L, CHEN L, ZHAO C-Z, ZHONG H, LI X-B (2012). Brassica napus PHR1 gene encoding a MYB-like protein functions in response to phosphate starvation. PLOS ONE 7: e44005.

ROBINSON NJ, PROCTER CM, CONNOLLY EL, GUERINOT ML (1999) A ferricchelate reductase for iron uptake from soils. Nature 397: 694-697.

ROGERS EE, EIDE DJ, GUERINOT ML (2000). Altered selectivity in an Arabidopsis metal transporter. Proc Natl Acad Sci USA 97: 12356-12360.

ROLLETSCHEK H, HOSEIN F, MIRANDA M, HEIM U, GÖTZ K-P, SCHLERETH A, BORISJUK L, SAALBACH I, WOBUS U, WEBER H (2005). Ectopic expression of an amino acid transporter (VfAAP1) in seeds of Vicia narbonensis and pea increases storage proteins. Plant Physiol 137: 1236-1249.

ROY RN, FINCKA, BLAIR, GJ, TANDON HLS (2006). Plant Nutrition for Food Security: A Guide for Integrated Nutrient Management (FAO Fertilizer and Plant Nutrition Bulletin 16). Food and Agriculture Organization of the United Nations, Rome.

RUBIN G, TOHGE T, MATSUDA F, SAITO K, SCHEIBLE W-R (2009). Members of the $L B D$ family of transcription factors repress anthocyanin synthesis and affect additional nitrogen responses in Arabidopsis. Plant Cell 21: 3567-3584.

RYANPR, DELHAIZEE, JONESDL (2001). Function and mechanisms of organic anion exudation from plant roots. Annu Rev Plant Physiol Plant Mol Biol 52: 527-560.

RYAN PR, TYERMAN SD, SASAKI T, FURUICHI T, YAMAMOTO Y, ZHANG WH, DELHAIZE E (2011). The identification of aluminium-resistance genes provides opportunities for enhancing crop production on acid soils. J Exp Bot 62: 9-20.

SANTI S, CESCO S, VARANINI Z, PINTON R (2005). Two plasma membrane $\mathrm{H}^{+}-$ ATPase genes are differentially expressed in iron-deficient cucumber plants. Plant Physiol Biochem 43: 287-292.

SANTI S, SCHMIDT W (2009). Dissecting iron deficiency-induced proton extrusion in Arabidopsis roots. New Phytol 183: 1072-1084.

SCHOFIELD RA, BIY-M, KANTS, ROTHSTEINSJ (2009). Over-expression of STP13, a hexose transporter, improves plant growth and nitrogen use in Arabidopsis thaliana seedlings. Plant Cell Environ 32: 271-285.

SEO H-M, JUNG Y, SONG S, KIM Y, KWON T, KIM D-H, JEUNG S-J, YI Y-B, YI G, NAM M-H, NAM J (2008). Increased expression of OsPT1, a high-affinity phosphate transporter, enhances phosphate acquisition in rice. Biotechnol Lett30: 1833-1838.

TAKAHASHI M, NAKANISHI H, KAWASAKI S, NISHIZAWA NK, MORI S (2001). Enhanced tolerance of rice to low iron availability in alkaline soils using barley nicotianamine aminotransferase genes. Nat Biotechnol 19: 466-469.

TAMURA W, HIDAKA Y, TABUCHI M, KOJIMA S, HAYAKAWA T, SATO T, OBARA M, KOJIMA M, SAKAKIBARA H, YAMAYA T (2010). Reverse genetics approach to characterize a function of $\mathrm{NADH}$-glutamate synthase 1 in rice plants. Amino Acids 39: 1003-1012.

TANG Z, FAN X, LI Q, FENG H, MILLER AJ, SHEN Q, XU G (2012). Knockdown of a rice stelar nitrate transporter alters long-distance translocation but not root influx. Plant Physiol 160: 2052-2063.

VAROTTO C, MAIWALD D, PESARESI P, JAHNS P, SALAMINI F, LEISTERD (2002). The metal ion transporter IRT1 is necessary for iron homeostasis and efficient photosynthesis in Arabidopsis thaliana. Plant J 31: 589-599.

VERT G, GROTZ N, DÉDALDÉCHAMP F, GAYMARD F, GUERINOT ML, BRIAT J-F, CURIE C (2002) IRT1, an Arabidopsis transporter essential for iron uptake from the soil and for plant growth. Plant Cell 14: 1223-1233.

VIDAL EA, ARAUS V, LU C, PARRY G, GREEN PJ, CORUZZI GM, GUTIÉRREZ RA (2010) Nitrate-responsive miR393/AFB3 regulatory module controls root system architecture in Arabidopsis thaliana. Proc Natl Acad Sci USA 107: 4477-4482.

WANG C, YING S, HUANG H, LI K, WU P, SHOU H (2009a) Involvement of OSSPX1 in phosphate homeostasis in rice. Plant J 57: 895-904.

WANG N, CUI Y, LIU Y, FAN H, DU J, HUANG Z, YUAN Y, WU H, LING H-Q (2013a). Requirement and functional redundancy of Ib subgroup bHLH proteins for iron deficiency responses and uptake in Arabidopsis thaliana. Mol Plant 6: 503-513.

WANG X, WANG Y, TIAN J, LIM BL, YAN X, LIAOH (2009b) Overexpressing AtPAP15 enhances phosphorus efficiency in soybean. Plant Physiol 151: 233-240.

WANG Y-Y, HSU P-K, TSAY Y-F (2012). Uptake, allocation and signaling of nitrate. Trends Plant Sci 17: 458-467.

WANG Y, YE X, DING G, XU F (2013b). Overexpression of phyA and appA genes improves soil organic phosphorus utilisation and seed phytase activity in Brassica napus. PLoS ONE 8: e60801.

WIRTH J, POLETTIS, AESCHLIMANN B, YAKANDAWALAN, DROSSE B, OSORIO S, TOHGET, FERNIEAR, GÜNTHER D, GRUISSEM W, SAUTTER C (2009). Rice endosperm iron biofortification by targeted and synergistic action of nicotianamine synthase and ferritin. Plant Biotechnol J 7: 631-644.

WU H, LI L, DU J, YUAN Y, CHENG X, LING H-Q (2005). Molecular and biochemical characterization of the $\mathrm{Fe}$ (III) chelate reductase gene family in Arabidopsis thaliana. Plant Cell Physiol 46: 1505-1514.

XIAO K, KATAGI H, HARRISON M, WANG Z-Y (2006). Improved phosphorus acquisition and biomass production in Arabidopsis by transgenic expression of a purple acid phosphatase gene from M. truncatula. Plant Sci 170: 191-202.

XU G, FAN X, MILLER AJ (2012). Plant Nitrogen Assimilation and use Efficiency. Annu Rev Plant Biol 63: 153-182.

YAMAYA, T OBARA, M NAKAJIMA H, SASAKI S, HAYAKAWA T, SATO T (2002). Genetic manipulation and quantitative-trait loci mapping for nitrogen recycling in rice. J Exp Bot 53: 917-925.

YANAGISAWA S, AKIYAMA A, KISAKA H, UCHIMIYA H, MIWA T (2004). Metabolic engineering with Dof1 transcription factor in plants: Improved nitrogen assimilation and growth under low-nitrogen conditions. Proc NatlAcad SciUSA 101: 7833-7838.

YUAN Y, WU H, WANG N, LI J, ZHAO W, DU J, WANG D, LING H-Q (2008). FIT interacts with $\mathrm{AtbH} \mathrm{LH} 38$ and $\mathrm{AtbH} \mathrm{LH} 39$ in regulating iron uptake gene expression for iron homeostasis in Arabidopsis. Cell Res 18: 385-397.

ZHENG L, YING Y, WANG L, WANG F, WHELAN J, SHOU H (2010). Identification of a novel iron regulated basic helix-loop-helix protein involved in $\mathrm{Fe}$ homeostasis in Oryza sativa. BMC Plant Biol 10: 166.

ZHOU J, JIAO FC, WU Z, LI Y, WANG X, HE X, ZHONG W, WU P (2008). OsPHR2 is involved in phosphate-starvation signaling and excessive phosphate accumulation in shoots of plants. Plant Physiol 146: 1673-1686. 


\section{Further Related Reading, published previously in the Int. J. Dev. Biol.}

Reproductive Meristem22 is a unique marker for the early stages of stamen development

Elisson Romanel, Pradeep Das, Richard M. Amasino, Jan Traas, Elliot Meyerowitz and Marcio Alves-Ferreira

Int. J. Dev. Biol. (2011) 55: 657-664

http://www.intjdevbiol.com/web/paper/113340er

Multi-probe in situ hybridization to whole mount Arabidopsis seedlings

Leonardo Bruno, Antonella Muto, Natasha D. Spadafora, Domenico laria, Adriana Chiappetta, Mieke Van Lijsebettens and Maria B. Bitonti

Int. J. Dev. Biol. (2011) 55: 197-203

http://www.intjdevbiol.com/web/paper/103132lb

Common themes in siRNA-mediated epigenetic silencing pathways

André Verdel, Aurélia Vavasseur, Madalen Le Gorrec and Leila Touat-Todeschini

Int. J. Dev. Biol. (2009) 53: 245-257

http://www.intjdevbiol.com/web/paper/082691av

Arabidopsis monomeric G-proteins, markers of early and late events in cell differentiation Mariette Bedhomme, Chantal Mathieu, Amada Pulido, Yves Henry and Catherine Bergounioux Int. J. Dev. Biol. (2009) 53: 177-185

http://www.intjdevbiol.com/web/paper/072488mb

\section{Plant microRNAs and development}

Sara Jover-Gil, Héctor Candela and María-Rosa Ponce

Int. J. Dev. Biol. (2005) 49: 733-744

http://www.intjdevbiol.com/web/paper/052015sj

Historical perspectives on plant developmental biology

Mieke Van Lijsebettens and Marc Van Montagu

Int. J. Dev. Biol. (2005) 49: 453-465

http://www.intjdevbiol.com/web/paper/041927ml

Molecular-genetic approach to study plant growth and development M Van Montagu, M Van Lijsebettens and D Inzé

Int. J. Dev. Biol. (1996) 40: S49-S50

http://www.intjdevbiol.com/web/paper/9087691

Mechanisms of the proliferation and differentiation of plant cells in cell culture systems H Fukuda, M Ito, M Sugiyama and A Komamine Int. J. Dev. Biol. (1994) 38: 287-299

http://www.intjdevbiol.com/web/paper/7981037

5 yr ISI Impact Factor $(2011)=2.959$
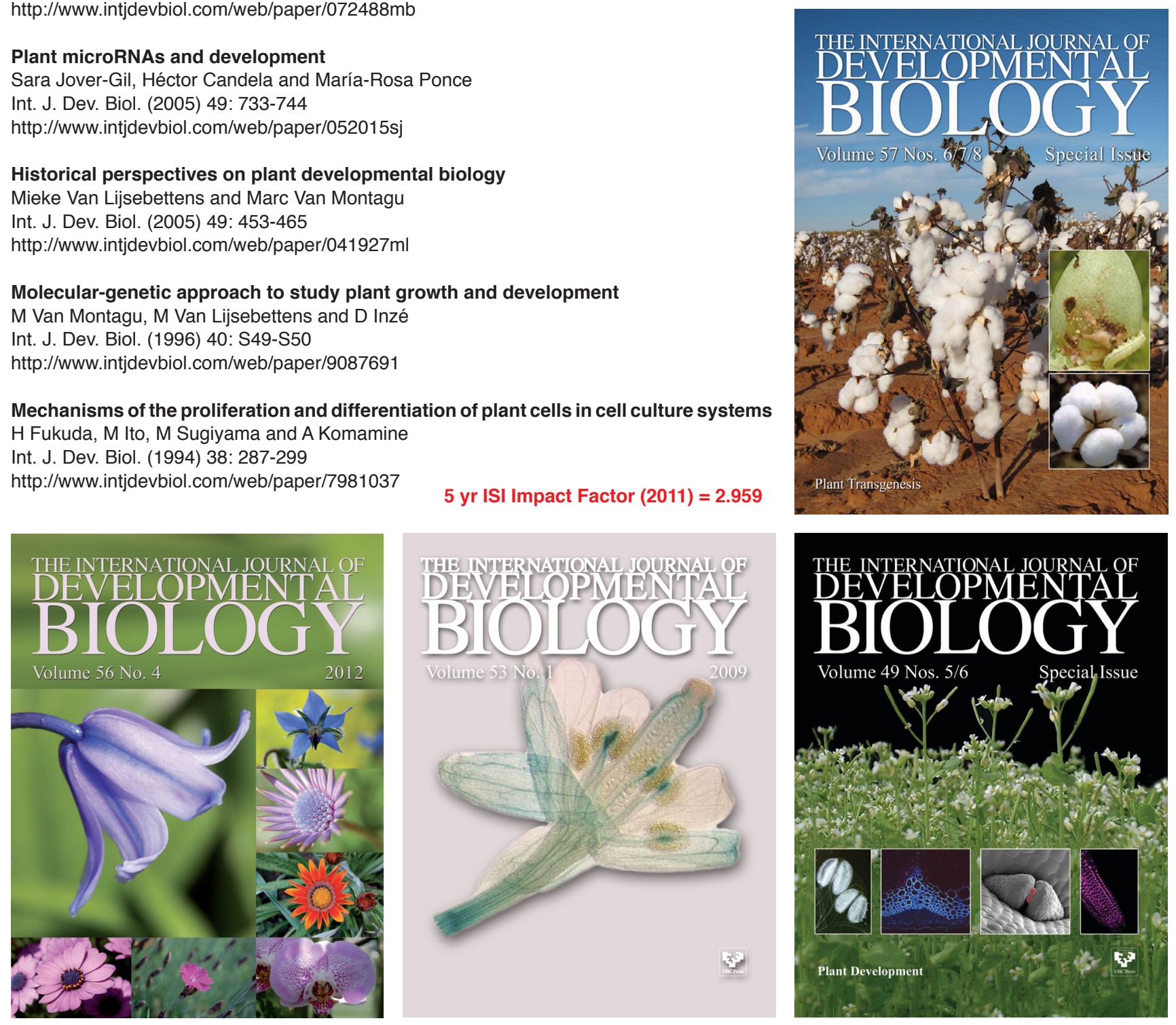